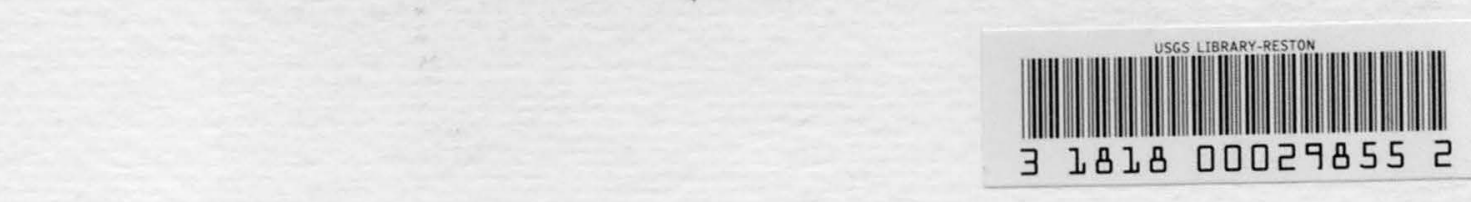

\title{
Hydrology of Malheur Lake, \\ Harney County, southeastern Oregon
}

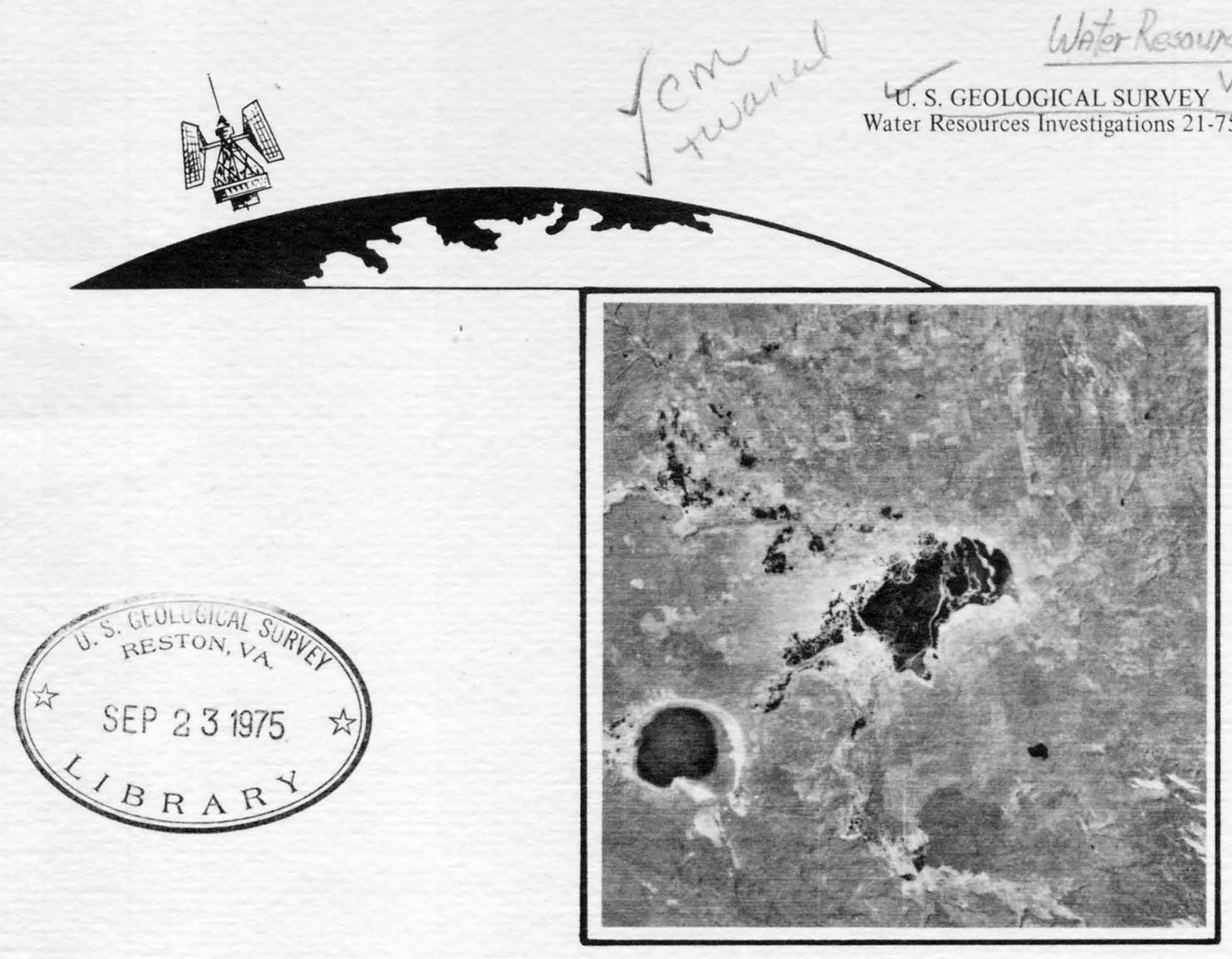

Prepared in cooperation with

U. S. ARMY CORPS OF ENGINEERS, Walla Walla District 


\begin{tabular}{|c|c|c|}
\hline $\begin{array}{l}\text { BISLIOGRAPHIC DATA } \\
\text { SHEET }\end{array}$ & 1. Report No. & 3. Recipient's Accession No. \\
\hline \multirow{2}{*}{\multicolumn{2}{|c|}{$\begin{array}{l}\text { 4. Title and Subtitle } \\
\text { HYDROLOGY OF MALHEUR LAKE, HARNEY COUNTY, SOUTHEASTERN } \\
\text { OREGON }\end{array}$}} & $\begin{array}{l}\text { 5. Report Date } \\
\text { August } 1975\end{array}$ \\
\hline & & 6. \\
\hline \multicolumn{2}{|l|}{$\begin{array}{l}\text { 7. Author(s) } \\
\text { Larry L. Hubbard }\end{array}$} & $\begin{array}{l}\text { 8. Performing Organization Rept. } \\
\text { No. USGS/WRI - } 21-75 \\
\end{array}$ \\
\hline \multicolumn{2}{|c|}{$\begin{array}{l}\text { 9. Performing Organization Name and Address } \\
\text { U.S. Geological Survey, Water Resources Division } \\
830 \mathrm{NE} \text {. Holladay Street } \\
\text { Portland, Oregon } 97232\end{array}$} & $\begin{array}{l}\text { 10. Project/Task/Work Unit No. } \\
\text { 11. Contract/Grant No. }\end{array}$ \\
\hline \multirow{2}{*}{\multicolumn{2}{|c|}{$\begin{array}{l}\text { 12. Sponsoring Organization Name and Address } \\
\text { U.S. Geological Survey, Water Resources Division } \\
830 \mathrm{NE} \text {. Holladay Street } \\
\text { Portland, Oregon } 97232\end{array}$}} & $\begin{array}{l}\text { 13. Type of Report \& Period } \\
\text { Covered } \\
\text { Final }\end{array}$ \\
\hline & & 14. \\
\hline
\end{tabular}

\section{Supplementary Notes}

Prepared in cooperation with the U.S. Army Corps of Engineers, Walla Walla District

16. Abstracts The various components of inflow and outflow to and from the lake and their relative magnitudes were identified. In 1972 water year the total inflow to the lake was 200,000 acre-feet, but it was only 75,000 acre-feet in 1973 water year. In 1972 water year the Donner und Blitzen River contributed 55 percent of the inflow, with Silvies River, direct precipitation, and Sodhouse Spring contributing 28, 13, and 4 percent respectively. In 1973 the Donner und Blitzen River contributed 61 percent of the inflow. The Silvies River, direct precipitation, and Sodhouse Spring contributed 1, 25, and 12 percent respectively. Ground-water inflow, other than Sodhouse Spring, appears to be negligible. In 1972 water year, 81 percent of the outflow was by evapotranspiration and 19 percent was surface outflow through The Narrows. In 1973, 96 percent of the outflow was by evapotranspiration and 4 percent was surface outflow through The Narrows. Ground-water outflow is negligible.

\section{Key Words and Document Analysis. 17a. Descriptors}

*Hydrologic equation, *Hydrologic budget, *Hydrologic data, *Lakes, Inflow, Water levels, Surface-groundwater relationships, Water storage, Discharge (water), Evapotranspiration.

17b. Identifiers/Open-Ended Terms

Harney Lake basin, Harney County, Closed-lake basins.

17c. COSATI Field/Group
18. Availability Statement
No restriction on distribution

\begin{tabular}{|l|c|}
\hline $\begin{array}{l}\text { 19. Security Class (This } \\
\text { Report) } \\
\text { UNCLASSIFIED }\end{array}$ & $\begin{array}{c}\text { 21. No. of Pages } \\
44\end{array}$ \\
\hline $\begin{array}{l}\text { 20. Security Class (This } \\
\text { Page } \\
\text { UNCLASSIFIED }\end{array}$ & 22. Price \\
\hline
\end{tabular}
USCOMM-DC 8265-P74 
HYDROLOGY OF MALHEUR LAKE, HARNEY COUNTY, SOUTHEASTERN OREGON

By Larry L. Hubbard

U. S. GEOLOGICAL SURVEY

Water Resources Investigations 21-75

Prepared in cooperation with

U. S. ARMY CORPS OF ENGINEERS,

Walla Walla District

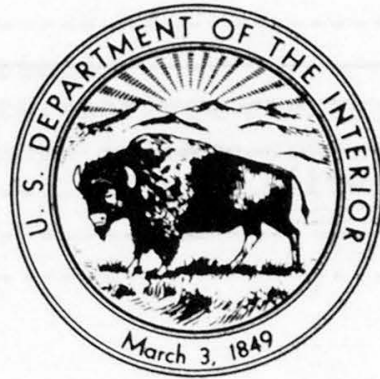

August 1975 


\section{UNITED STATES DEPARTMENT OF THE INTERIOR}

Stanley K. Hathaway, Secretary

GEOLOGICAL SURVEY

Vincent E. McKelvey, Director

For additional information write to:

U.S. Geological Survey

P. 0. Box 3202

Portland, Oregon 97208 
Abstract-1

Introduction-1...

Description of study area

Acknowledgments -

Purpose and scope-1... 3

Methods of investigation-1... 4

Data collection-1.- 4

Water-budget system-1. 7

The water budget-1. 7

Inflow to Malheur Lake-... 10

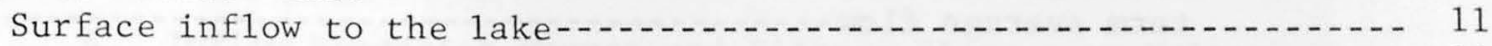

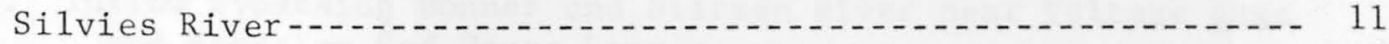

West Fork Silvies-_... 12

East Fork Silvies-1... 12

Floodflows bypassing East Fork and West Fork gages--..-- 12

Net flow of the Silvies reaching lake-..... 12

Flow of the Silvies River during the study period compared to the long-term average-... 13

Effects on flow of upstream management practices-..... 13

Donner und Blitzen River-_.......... 15

Flow of the Donner und Blitzen River during the study period compared to the long-term average-... 17

Effects of upstream management practices-......... 17

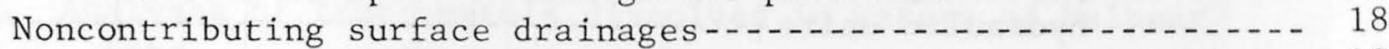

Inflow from direct precipitation on the lake surface-1........ 19

Ground-water inflow-_._. 20

Seepage into lake from the ground-water table-1...... 20

Sodhouse Spring-_... 20

Outflow from Malheur Lake-... 23

Surface outflow-1

Evapotranspiration 1 osses-1. 23

Ground-water outflow-1-

Change in lake contents-1... 25

Lake water-surface elevations-_.

Determination of lake water-surface areas

Estimation of monthly change in lake contents 31

Evaluation of water budget

Water quality- 32

Selected references 


\section{ILLUSTRATIONS}

Page

Figure 1. Map of Oregon showing location of study area-...

2. Map showing locations of data-collection points-...... 5

3. Photograph showing stage-recording gage and deflection-vane meter on East Fork of Silvies River-... 6

4. Graph showing relationship of flow in Silvies River near Burns and the flow in Donner und Blitzen River near Frenchglen during 1972 and 1973 water years to the 1ongterm average flow

5. Hydrographs for the Silvies River comparing flows passing the gaging station near Burns with flows reaching Malheur Lake-

6. Hydrographs of the Donner und Blitzen River comparing flows passing the Frenchglen gaging station with flows passing the Voltage gaging station

7. Map showing locations of ground-water observation we11s and graphs showing water-table profiles-...

8. Map showing locations of water-level gaging sites and hydraulic units

9. Graphs showing water-surface elevations at Malheur Lake at break in Cole Island Dike and Malheur Lake Outlet at The

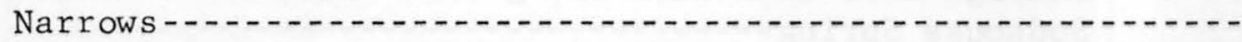

10. ERTS-1 imagery showing water surface of Malheur Lake throughout a range of lake levels

11. Graphs showing area curves of Malheur Lake-1... 30

12. Map showing locations of water-quality sampling sites, and specific conductance and streamflow near the end of March 1972 
TABLES

Page

Table 1. Malheur Lake monthly water budget showing inflow, outflow, and change in lake contents from March 1, 1972, to

September 30, $1973 \ldots$

2. Yearly water budgets for Malheur Lake for 1972 and 1973

water years

3. Inflow to Malheur Lake that bypassed East Fork and West Fork

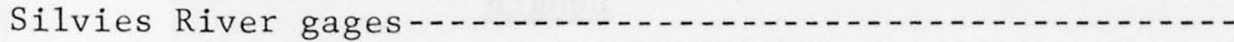

4. Inflow bypassing Donner und Blitzen River near Voltage gage

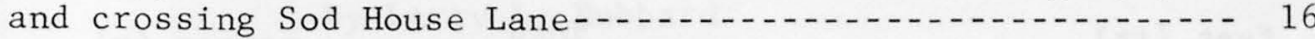

5. Inflow to Malheur Lake from Malheur Slough-... 19

6. Inflow at Sodhouse Spring

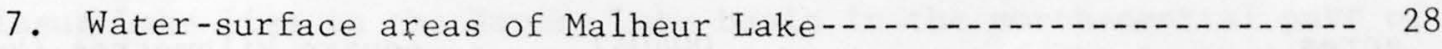

8. Chemical analyses of water samples at miscellaneous sites on

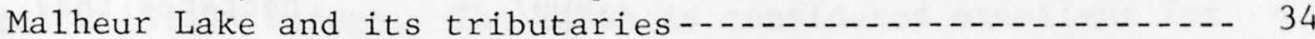

9. Analyses of trace metals dissolved in waters of Malheur

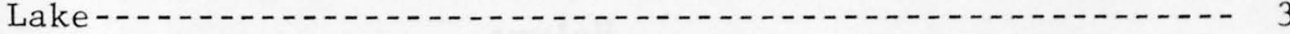

10. Chemical analyses of bottom-sediment samples of miscellaneous sites in Ma1heur Lake-1... 39 
FACTORS FOR CONVERTING ENGLIGH UNITS TO INTERNATIONAL SYSTEM UNITS (SI) The following factors may be used to convert the English units in this report to the International System of Units (SI).

Multiply English units

By

To obtain SI units

\section{Length}

inches (in.)

feet ( $\mathrm{ft}$ )

miles (mi)

acres

square miles $\left(\mathrm{mi}^{2}\right)$

cubic feet $\left(\mathrm{ft}^{3}\right)$

acre-feet (acre-ft)

cubic feet per second $\left(\mathrm{ft}^{3} / \mathrm{s}\right)$
25.4

.3048

1.609

Area

.004047

.4047

2.590

$\underline{\text { Volume }}$

.02832

$1.233 \times 10^{-3}$

$1.233 \times 10^{-6}$

Flow

.02832 millimetres (mm)

metres (m)

kilometres ( $\mathrm{km})$

square kilometres $\left(\mathrm{km}^{2}\right)$

hectares (ha)

square kilometres $\left(\mathrm{km}^{2}\right)$

cubic metres $\left(\mathrm{m}^{3}\right)$

cubic hectometres $\left(\mathrm{hm}^{3}\right)$

cubic kilometres $\left(\mathrm{km}^{3}\right)$ cubif metres per secon
$\left(\mathrm{m}^{3} / \mathrm{s}\right)$ 


\title{
HYDROLOGY OF MALHEUR LAKE, HARNEY COUNTY, SOUTHEASTERN OREGON
}

\author{
By Larry L. Hubbard
}

\begin{abstract}
Malheur Lake lies in the Harney Lake basin in the north-central part of Harney County in southeastern Oregon. The lake is one of the largest freshwater marshes in the United States and is one of the main units of the Malheur National Wildlife Refuge. The marsh is considered excellent for waterfowl production as well as a vital migration habitat for birds in the Pacific Flyway.

Because of the importance of the wildlife refuge, any management plan for the basin needs to consider the impact of management alternatives on the hydrology of Malheur Lake. Various water-management agencies are making studies to develop land-use and water-resource alternatives in Harney Valley. As part of one of these studies, the U.S. Geological Survey engaged in an intensive water-data collection program at Malheur Lake, Oreg., from March 1, 1972, through September 30, 1973. The study was made to identify the various components of inflow and outflow to and from the lake and to determine the relative magnitude of these components.
\end{abstract}

The 1972 water-year data represent very high runoff, whereas the 1973 water-year data represent very low runoff. The total inflow to the lake was 200,000 acre-feet (250 cubic hectometres) in 1972 water year and only 75,000 acre-feet (90 cubic hectometres) in 1973 water year.

In 1972 water year the Donner und Blitzen River contributed 55 percent of the inflow, with the Silvies River, direct precipitation, and Sodhouse Spring contributing 28, 13, and 4 percent respectively. In 1973 water year the Donner und Blitzen River was again the principal contributor of water to the lake, contributing 62 percent of the total inflow. The Silvies River, direct precipitation, and Sodhouse Spring contributed 1, 25, and 12 percent respectively. Ground-water inflow, other than Sodhouse Spring, appears to be negligible. 
A comparison of flows monitored near the inflow points to the lake with records of flow for upstream gaging stations reflects the extensive diversions for irrigation in the Silvies River basin and for refuge management in the Donner und Blitzen River basin. Because of these diversions, a large quantity of the annual snowmelt runoff does not reach Malheur Lake.

In 1972 water year, 81 percent of the outflow was by evapotranspiration and 19 percent was surface outflow through The Narrows. In 1973 water year, 96 percent of the outflow was by evapotranspiration and 4 percent was surface outflow through The Narrows. Ground-water outflow appears to be negligible.

Water-quality samples were taken at a11 inflow and outflow points and at eight points within the lake. In general, the water in the lake is rather dilute, largely because all inflow sources are low in dissolved solids; however, relatively high values of specific conductance were measured on the east side of Cole Island Dike. This condition apparently results because there is no direct flushing by water flowing through this part of the lake. Because of the complex hydraulics of the lake, the chemical quality differs greatly with time and from point to point. At the end of March 1972, the specific conductance of the lake water ranged from 280 to 2,040 micromhos at different locations on the lake. At one sampling site, the specific conductance ranged from 2,040 to 6,770 micromhos during the study, whereas at another point the range was from 280 to 450 micromhos.

Analysis of bottom-sediment samples indicated only very small quantities of trace metals other than aluminum. Samples analyzed indicated no pesticides other than minute quantities of DDE.

\section{INTRODUCTION}

\section{Description of Study Area}

Ma1heur Lake lies in the Harney Lake basin in the north-central part of Harney County in southeastern Oregon (fig. 1). The lake is in effect a freshwater marsh, one of the largest in the United States. Historically, it has been dry during extreme droughts, and at high-water levels the surface area exceeds 50,000 acres $(20,000 \mathrm{ha})$. At highest water levels, the depth of water is only about 6 feet $(2 \mathrm{~m})$ in the deepest parts of the lake. The lake surface is interspersed with emergent plants and open water. The drainage area of the lake is 2,100 square miles $\left(5,400 \mathrm{~km}^{2}\right)$. Overflow from Malheur Lake passes through Mud Lake into Harney Lake, the end of the closed basin.

Malheur Lake is one of the main units of the Malheur National Wildlife Refuge. The Malheur Lake marsh is considered excellent for waterfowl production as well as a vital migration habitat for birds in the Pacific Flyway. 


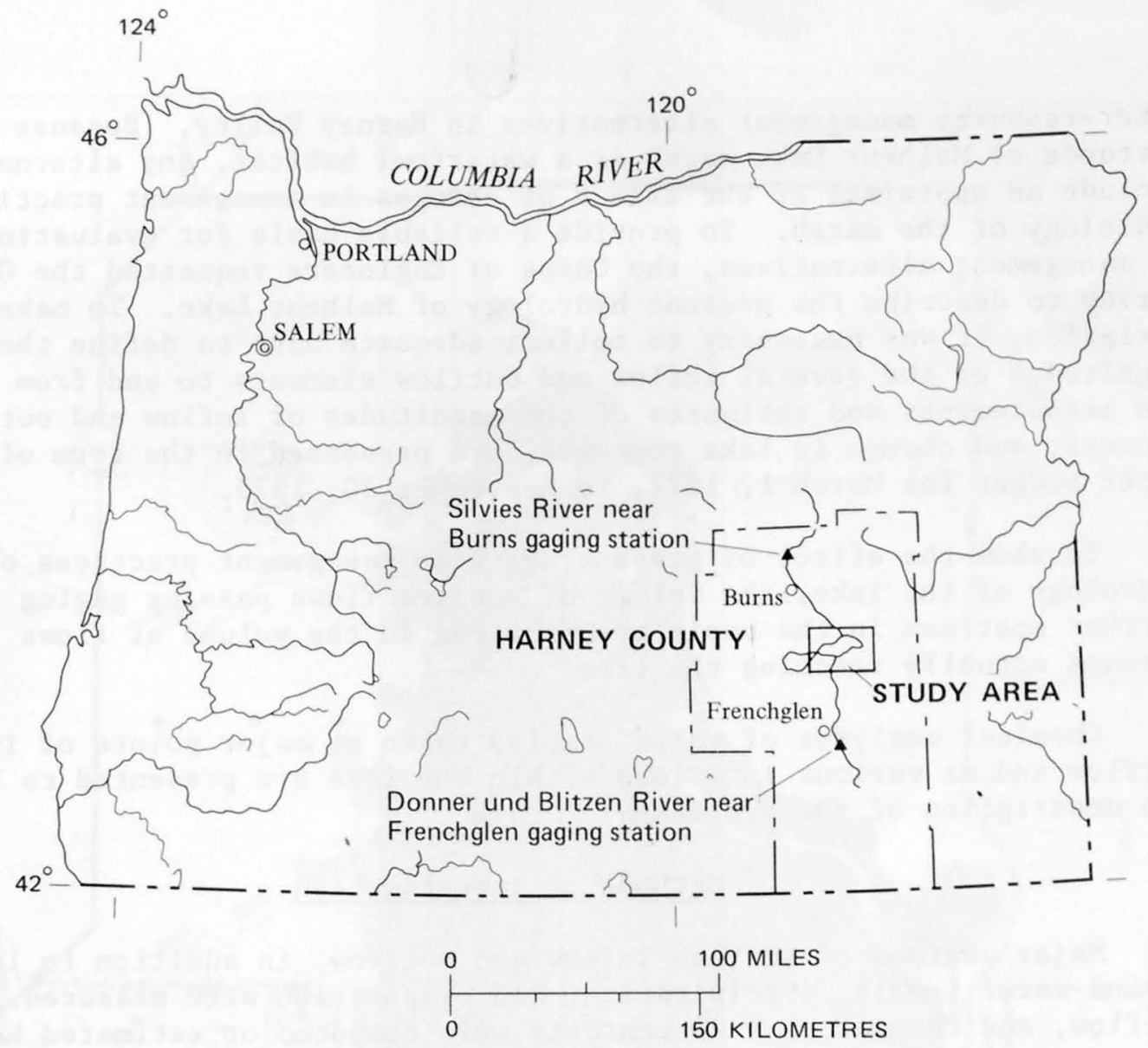

Figure 1 - Location of study area.

\section{Acknowledgments}

The cooperation and assistance of many individuals greatly facilitated this study. Joseph P. Mazzoni, manager of the Malheur National Wildlife Refuge, provided equipment and assistance from refuge personnel during the construction and data-collection phase of the study. The weather station at refuge headquarters was operated by refuge personnel. Two individuals from the refuge who deserve special credit are Eldon L. McLaury and Richard E. Toltzman, who piloted the refuge airboat that was used in obtaining water samples for chemical analysis. The airboat was also used in making a reconnaissance to determine all possible sources of surface inflow.

Phillip W. Hiibel, watermaster for the Oregon State Engineer, made flow measurements and rendered assistance in the field.

\section{$\underline{\text { Purpose and Scope }}$}

The U.S. Army Corps of Engineers, which has been studying the feasibility of providing storage on the Silvies River for flood control, irrigation, and recreation, is one of several agencies making studies to develop land-use and 
water-resource management alternatives in Harney Valley. Because of the importance of Malheur Lake marsh as a waterfowl habitat, any alternatives must include an appraisal of the effect of changes in management practices on the hydrology of the marsh. To provide a reliable basis for evaluating the impact of management alternatives, the Corps of Engineers requested the Geological Survey to describe the present hydrology of Malheur Lake. To make that description, it was necessary to collect adequate data to define the relative magnitudes of the several inflow and outflow elements to and from the lake. The measurements and estimates of the magnitudes of inflow and outflow, components, and change in lake contents, are presented in the form of a monthly water budget for March 1, 1972, to September 30, 1973.

To show the effect of present upstream management practices on the hydrology of the lake, the volume of surface flows passing gaging stations farther upstream in the basin are compared to the volume of flows for the same streams actually reaching the lake.

Chemical analyses of water samples taken at major points of inflow and outflow and at various locations within the lake are presented to supplement the description of the hydrology.

\section{Methods of Investigation}

Major sources of surface inflow and outflow, in addition to lake levels, ground-water levels, precipitation, and evaporation were measured. Inflow, outflow, and changes in lake contents were computed or estimated based on the measured values. The results are tabulated and presented in the form of a water budget.

\section{Data Collection}

The principal data-collection points used in this study lie near or within the high-water perimeter of the lake, as shown in figure 2. Records from two streamflow gaging stations outside the study area near Burns and Frenchglen were used for comparison (fig. 1).

The inflow from Donner und Blitzen River near Voltage was monitored with a conventional stream-gaging station below Sod House Dam (fig. 2). During the irrigation season, flow is diverted at Sod House Dam; some of this water reaches the lake as irrigation waste water. The volume of irrigation waste water reaching the lake was estimated from current-meter measurements at as many as 15 bypass points and from the appearance of the gage-height trace at the Voltage gaging station. Changes in rates of diversion were reflected as breaks in the trend of the recorder trace.

Inflow to Malheur Lake from the Silvies River was monitored at gaging stations on the East and West Forks. Flows that bypassed the gaging station during the runoff season were measured periodically at as many as 12 bridges and culverts between the two forks. Because of variable backwater from Malheur Lake, the gaging stations were equipped with water-stage recorders and recording velocity-deflection meters (fig. 3). 


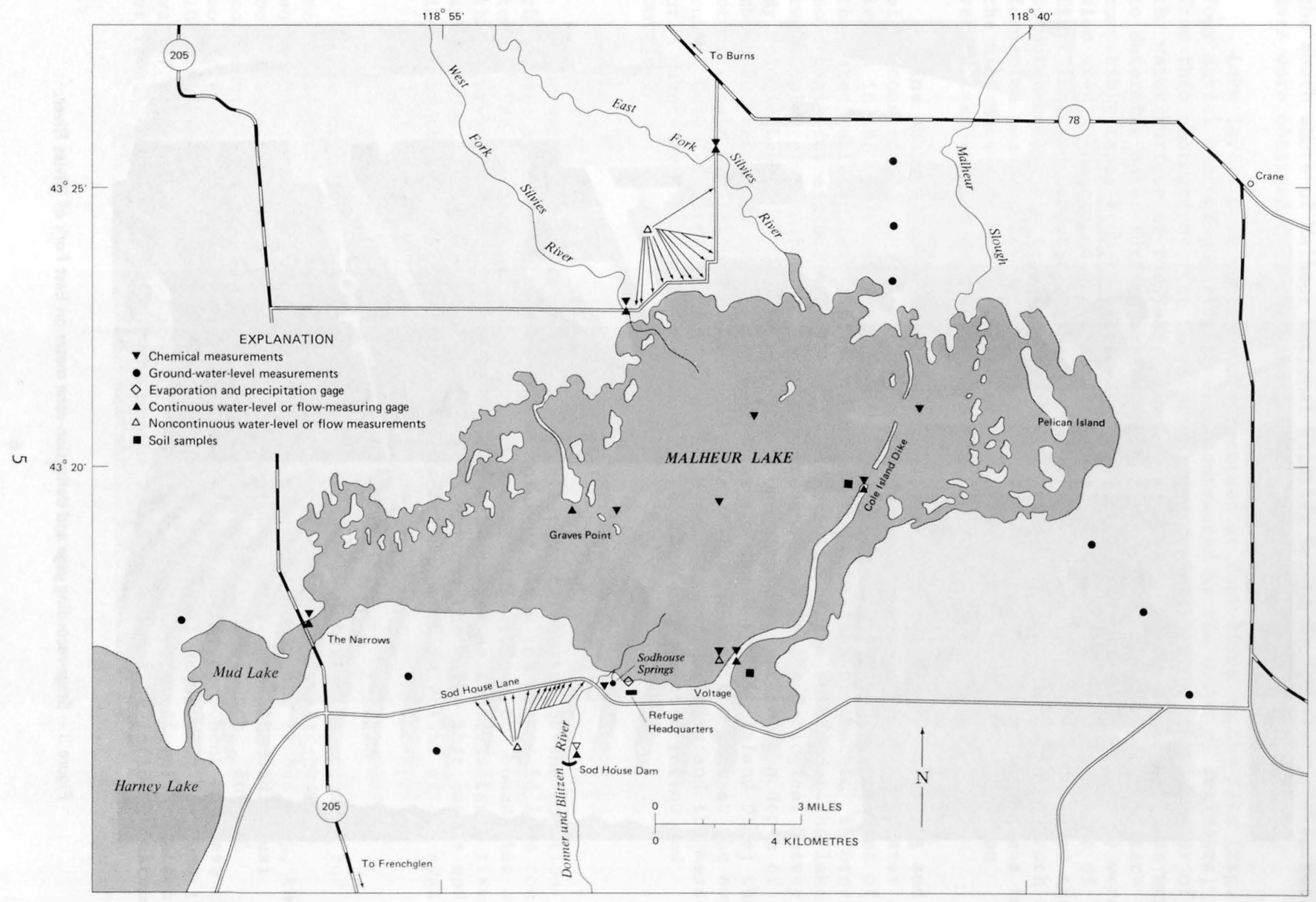

Figure 2 - Location of data-collection points. 


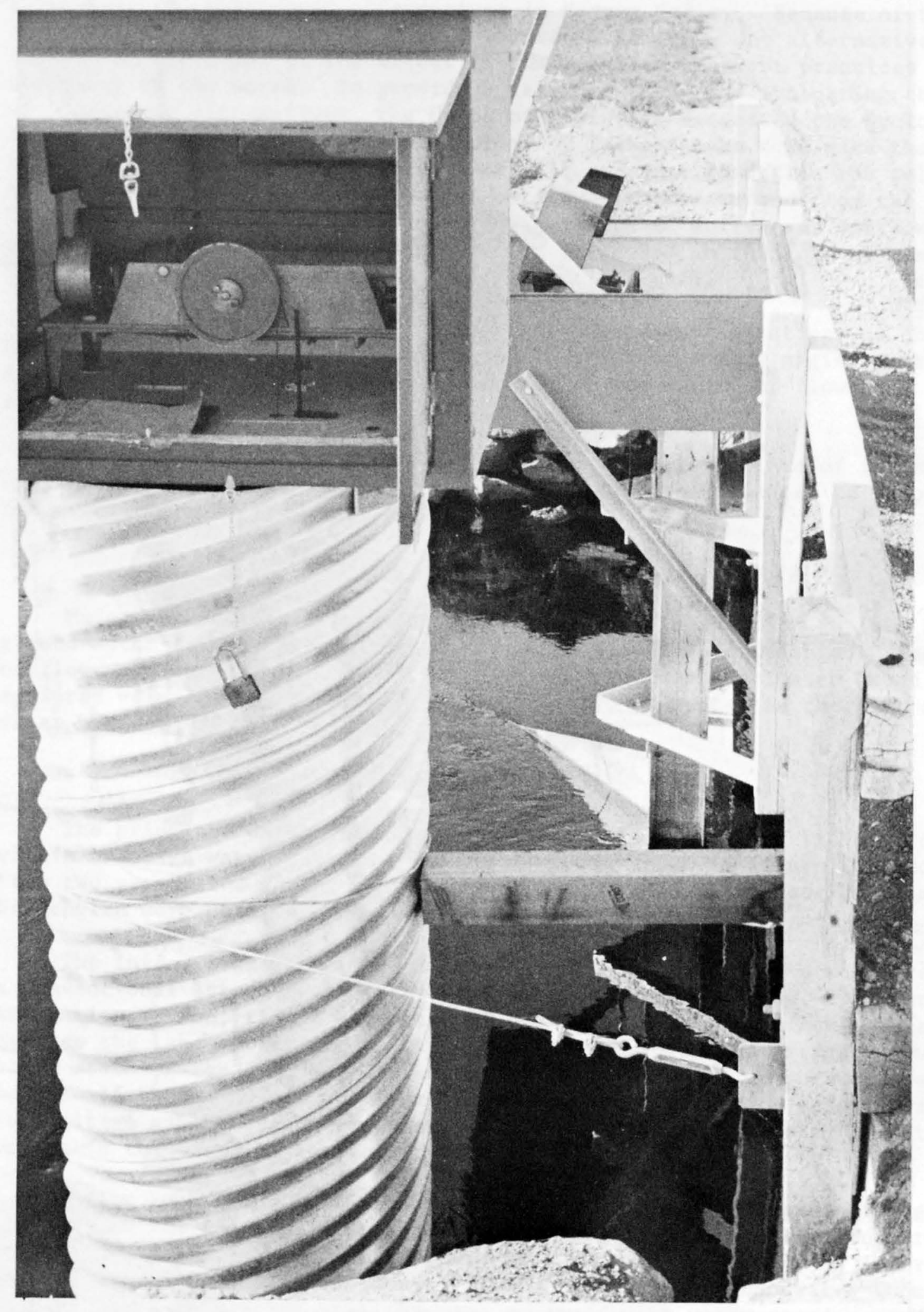

Figure 3 - Stage-recording gage and deflection-vane meter on East Fork of Silvies River. 
Precipitation data were obtained from a gage at the weather station near the south shore of Malheur National Wildlife Refuge Headquarters. Evaporation data were obtained from the same weather station.

Lake levels were continuously recorded at four sites on the lake (fig. 2 ). Four aerial photography flights were contracted by the Corps of Engineers; from this photography, the Corps prepared maps delineating the perimeter of the water surface of the lake. The Geological Survey planimetered these maps to determine water-surface areas. Nine data sets in the form of computercompatible tapes from the Earth Resources Technology Satellite (ERTS-1) were also used to determine water-surface areas of the lake. The Department of Electrical and Computer Engineering at Oregon State University processed the computer-compatible tapes and, with data from these tapes and ground-truth information provided by the Geological Survey, computed water-surface areas for the nine data sets. These data were plotted to determine lake elevation versus lake-surface area relationships.

Nine shallow ground-water observation wells (fig. 2), one existing and eight constructed for this study, were surveyed to sea-level datum. Water levels in the wells were measured periodically to determine the gradient of the water table on four lines perpendicular to the lake perimeter. To provide some basis for estimating hydraulic conductivity of the soil under the lake, two samples of lake-bottom sediments were analyzed by the Geological Survey Hydrologic Laboratory in Denver, Colo. One sample was taken at a depth of about 20 feet $(6 \mathrm{~m})$ near the lake gage at the break in Cole Island Dike; the other sample was taken at a depth of 2 feet $(0.6 \mathrm{~m})$ near the gage at the south end of Cole Island Dike. The estimated hydraulic conductivity and the measured water-level gradients were used to estimate ground-water inflow and outflow.

Water-Budget System

The water budget as presented in this report is based on the equation that total inflow equals total outflow plus or minus the change in lake contents. The lake bottom, shoreline, and water surface form the boundaries of the water-budget system, the volume of which changes as the lake level rises and recedes. The budget describes quantitatively the water that enters and leaves at the boundaries of the system and the change in volume of the system.

\section{THE WATER BUDGET}

The monthly water budgets presented in table 1 have been adjusted for residual error. In the first computation of the monthly water-budget equations, the total error was shown as a residual. In the second step, the budget equation was balanced by prorating that error among the individual components, based on the original estimated magnitude of each. For all months except one, the adjustment to each water-budget component was less than 10 percent of its original estimated value. Residual adjustment for June 1972 was 17 percent. Nine of the months required an adjustment of only 5 percent or less. About one-third of the months required a negative inflow adjustment 
Table 1.--Malheur Lake monthly water budget showing inflow, outflow, and change in lake contents, in acre-feet, for the period March 1, 1972, to September 30, 1973

$\infty$

\begin{tabular}{|c|c|c|c|c|c|c|c|c|c|c|c|c|c|}
\hline \multicolumn{14}{|c|}{1972 water year } \\
\hline & Oct. & Nov. & Dec. & Jan. & Feb. & Mar. & Apr. & May & June & July & Aug. & Sept. & $\begin{array}{l}\text { Mar. } 1- \\
\text { Sept. } 30 \\
\text { total }\end{array}$ \\
\hline \multicolumn{14}{|l|}{ INFLOW } \\
\hline Silvies River & -- & -- & -- & -- & -- & 25,800 & 23,300 & 2,000 & 700 & 0 & 0 & 0 & 51,800 \\
\hline Donner und Blitzen & -- & -- & -- & -- & -- & 24,000 & 5,200 & 11,000 & 18,800 & 5,200 & 2,500 & 2,600 & 69,300 \\
\hline Sodhouse Spring & -- & -- & -- & -- & -- & 700 & 700 & 700 & 700 & 700 & 700 & 700 & 4,900 \\
\hline $\begin{array}{l}\text { Direction precipi- } \\
\text { tation }\end{array}$ & -- & -- & -- & -- & -- & 8,000 & 900 & 3,200 & 1,500 & 0 & 1,800 & 1,700 & 17,100 \\
\hline Total inflow & -- & -- & -- & -- & - & 58,500 & 30,100 & 16,900 & 21,700 & 5,900 & 5,000 & 5,000 & 143,100 \\
\hline \multicolumn{14}{|l|}{ OUTFLOW } \\
\hline Outlet at Narrows & -- & - & -- & - & -- & 7,800 & 12,600 & 11,900 & 5,700 & 1,700 & 100 & 0 & 39,800 \\
\hline $\begin{array}{l}\text { Evapotranspi- } \\
\text { ration }\end{array}$ & -- & -- & -- & -- & -- & 6,600 & 21,700 & 27,600 & 38,500 & 30,800 & 21,800 & 10,800 & 157,800 \\
\hline Tota 1 outflow & -- & -- & -- & -- & -- & 14,400 & 34,300 & 39,500 & 44,200 & 32,500 & 21,900 & 10,800 & 197,600 \\
\hline CHANGE IN CONTENTS & -- & -- & -- & -- & -- & 44,100 & $-4,200$ & $-22,600$ & $-22,500$ & $-26,600$ & $-16,900$ & $-5,800$ & $-54,500$ \\
\hline
\end{tabular}


Table 1.--Malheur lake monthly water budget showing inflow, outflow, and change in lake contents, in acre-feet, for the period March 1, 1972, to September 30, 1973--Continued

\begin{tabular}{|c|c|c|c|c|c|c|c|c|c|c|c|c|c|}
\hline & & & & & & $1973 \mathrm{w}$ & ater year & & & & & & \\
\hline & Oct. & Nov. & Dec. & Jan. & Feb. & Mar. & Apr. & May & June & July & Aug. & Sept. & total \\
\hline \multicolumn{14}{|l|}{ INFLOW } \\
\hline Silvies River & 0 & 0 & 0 & 200 & 500 & 300 & 0 & 0 & 0 & 0 & 0 & 0 & 1,000 \\
\hline Donner und Blitzen & 3,400 & 4,700 & 6,700 & 7,300 & 3,800 & 2,500 & 2,000 & 10,000 & 2,600 & 900 & 1,000 & 1,300 & 46,200 \\
\hline Sodhouse Spring & 700 & 700 & 700 & 700 & 700 & 700 & 700 & 700 & 700 & 800 & 900 & 900 & 8,900 \\
\hline $\begin{array}{l}\text { Direct precipi- } \\
\text { tation }\end{array}$ & 600 & 2,900 & 3,800 & 2,300 & 1,800 & 1,900 & 1,300 & 2,300 & 300 & 0 & 300 & 1,200 & 18,700 \\
\hline Total inflow & 4,700 & 8,300 & 11,200 & 10,500 & 6,800 & 5,400 & 4,000 & 13,000 & 3,600 & 1,700 & 2,200 & 3,400 & 74,800 \\
\hline \multicolumn{14}{|l|}{ OUTFLOW } \\
\hline Outlet àt Narrows & 0 & 0 & 0 & 100 & 600 & 1,300 & 600 & 600 & 300 & 0 & 0 & 0 & 3,500 \\
\hline $\begin{array}{l}\text { Evapotranspi- } \\
\text { ration }\end{array}$ & 6,600 & 1,500 & 0 & 0 & 0 & 7,400 & 14,800 & 18,300 & 18,200 & 16,600 & 10,400 & 5,600 & 99,400 \\
\hline Total outflow & 6,600 & 1,500 & 0 & 100 & 600 & 8,700 & 15,400 & 18,900 & 18,500 & 16,600 & 10,400 & 5,600 & 102,900 \\
\hline CHANGE IN CONTENTS & $-1,900$ & $+6,800$ & $+11,200$ & $+10,400$ & $+6,200$ & $-3,300$ & $-11,400$ & $-5,900$ & $-14,900$ & $-14,900$ & $-8,200$ & $-2,200$ & $-28,100$ \\
\hline
\end{tabular}


(with a corresponding positive outflow adjustment). The remaining months required positive inflow adjustments and negative outflow adjustments.

Water budgets for the 1972 and 1973 water years are presented in table 2 . The systematic data-collection phase of the study did not begin until March 1 , 1972; therefore, all the components of the budget had to be estimated for October 1, 1971, through February 29, 1972. For the following reasons, it was possible to adequately estimate the volumes of inflow and outflow for this period:

1. From discussions with ranchers in the area, it was determined that no flow had reached the lake from the Silvies River from October 1 to

February 1. The February inflow from the Silvies to the lake was estimated from a field estimate of flow made in February and the appearance of the hydrograph for Silvies River near Burns gaging station.

2. The missing-record period occurred when there were no diversions for irrigation from the Donner und Blitzen River and a reliable correlation could be made to determine the flow reaching the lake by using the records from Donner und Blitzen River near Frenchglen gaging station.

3. When lake levels are at medium stage or higher, the flows out of Sodhouse Spring are extremely steady.

4. Precipitation records were available for this period.

5. Water did not start flowing out through The Narrows until late February (based on field observations).

6. Evapotranspiration losses are very small at this time of year.

7. With the exception of the Donner und Blitzen River and Sodhouse Spring, both of which could be estimated quite reliably, all the flow components represented a small fraction of the total 1972 water-year budget.

For the 1972 water-year budget, the residual of the water-budget equation was considered to represent the change in contents of the lake. The change in contents for the 1973 water year was computed directly from data collected during this study.

\section{INFLOW TO MALHEUR LAKE}

Inflow of water to Malheur Lake is from four principal sources--surface runoff from the Silvies and Donner und Blitzen Rivers, Sodhouse Spring on the periphery of the lake, and direct precipitation on the lake surface. 
Table 2.--Yearly water budgets for Malheur Lake for $1972 \underline{1}$ and 1973 water years

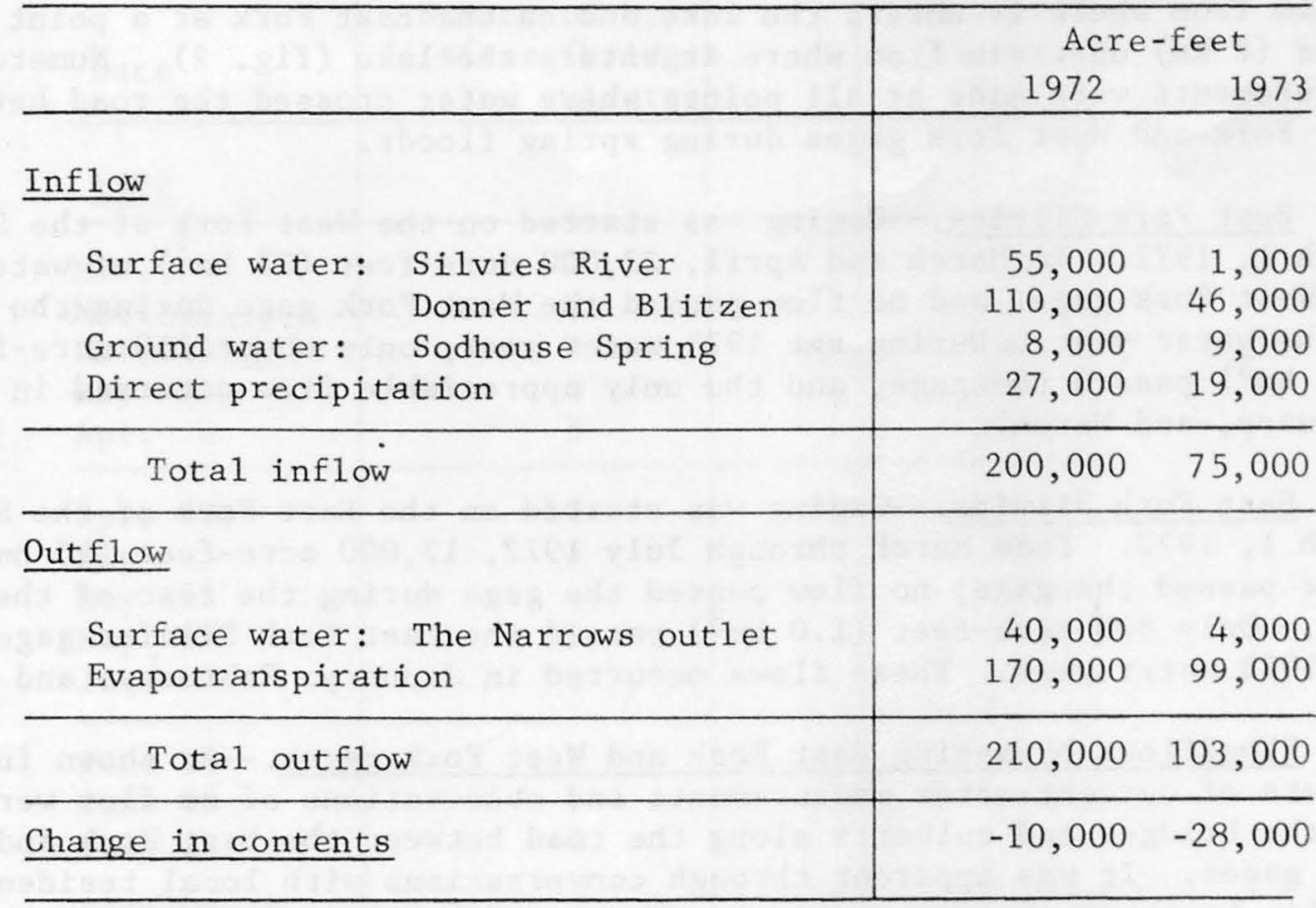

1/ Period from October 1, 1971, through February 29, 1972, precedes data-collection phase of study. Quantities of water are estimated for this period and are considered to be reliable for determining relative magnitudes of sources of inflow, outflow, and change in contents.

\section{Surface Inflow to the Lake}

\section{Silvies River}

The Silvies River is the second largest source of surface runoff into Malheur Lake. It has a drainage area of approximately 1,200 square miles $\left(3,100 \mathrm{~km}^{2}\right)$ and a channel length of $140 \mathrm{miles}(230 \mathrm{~km})$ from its source to the point where the West Fork enters Malheur Lake. The channel slope of the basin averages 6 feet per mile $(1 \mathrm{~m} / \mathrm{km})$, but it is no more than 2 feet per mile $(0.4 \mathrm{~m} / \mathrm{km})$ in the lower Harney Valley, from Burns to the lake. The average elevation of the basin is about 5,000 feet $(1,500 \mathrm{~m})$. The upper part of the basin is mainly forested and the lower part is mainly semiarid rangeland and irrigated cropland.

The Silvies River forks into two distributaries, the East Fork and the West Fork, at a bifurcation about 1.5 miles $(2.5 \mathrm{~km})$ downstream from the town of Burns and about 30 miles $(50 \mathrm{~km})$ upstream from where the West Fork enters the lake. 
During spring flooding, water enters the lake through the East Fork and West Fork channels and at many points between the two channels. During the study, flow was gaged on the West Fork at a point about 2 miles ( $3 \mathrm{~km}$ ) upstream from where it enters the lake and on the East Fork at a point about 5 miles $(8 \mathrm{~km})$ upstream from where it enters the lake (fig. 2). Numerous flow measurements were made at all points where water crossed the road between the East Fork and West Fork gages during spring floods.

West Fork Silvies.--Gaging was started on the West Fork of the Silvies on March 1, 1972. In March and April, 22,000 acre-feet (27 hm $\mathrm{hm}^{3}$ ) of water passed the West Fork gage, and no flow passed the West Fork gage during the remainder of the water year. During the 1973 water year, only about 150 acre-feet $\left(0.2 \mathrm{hm}^{3}\right)$ passed the gage, and the only appreciable flow occurred in January, February, and March.

East Fork Silvies.--Gaging was started on the East Fork of the Silvies on March 1, 1972. From March through July 1972, 12,000 acre-feet (15 $\left.\mathrm{hm}^{3}\right)$ of water passed the gage; no flow passed the gage during the rest of the water year. Only 800 acre-feet $\left(1.0 \mathrm{hm}^{3}\right)$ passed the East Fork Silvies gage during the 1973 water year. These flows occurred in January, February, and March.

Floodflows bypassing East Fork and West Fork gages. --As shown in table 3, 13 sets of current-meter measurements and observations of no flow were made at all the bridges and culverts along the road between the East Fork and West Fork gages. It was apparent through conversations with local residents that no flow bypassed the gages prior to March 1972 during the 1972 water year. A total of about 18,000 acre-feet $\left(22 \mathrm{hm}^{3}\right)$ bypassed the East Fork and West Fork gages during the 1972 water year. No water bypassed the gages and entered the lake during the 1973 water year.

Net flow of the Silvies reaching lake.--Previous studies have suggested that the Silvies River is the principal contributor of inflow to Malheur Lake. In contrast, this study shows that the Donner und Blitzen River is the principal contributor. Previous studies were apparently in error in that they assumed that the flow passing Silvies River near Burns gaging station about 55 miles $(88 \mathrm{~km})$ upstream from the lake and the flow passing Donner und Blitzen River near Frenchglen gaging station about 45 miles (72 km) upstream from the lake were representative of flows reaching the lake. Because of the large quantities of irrigation water diverted below these gaging stations, this is not true. During this study the flows of the Silvies and Donner und Blitzen Rivers were gaged and measured as far downstream as practicable.

During March through September 1972, 51,800 acre-feet (64 $\left.\mathrm{hm}^{3}\right)$ entered Malheur Lake from the Silvies River basin. Reliable estimates indicate that about 55,000 acre-feet $\left(68 \mathrm{hm}^{3}\right)$ entered the lake from the Silvies River during the 1972 water year. This represents about 28 percent of the total inflow and 33 percent of the total surface inflow. Only 1,000 acre-feet $\left(1 \mathrm{hm}^{3}\right)$ from the Silvies reached the lake during the 1973 water year. This is about 1 percent of the total inflow and 2 percent of the surface inflow. 
Table 3.--Inflow to Ma1heur Lake that bypassed East Fork and West Fork Silvies River gages

\begin{tabular}{l|c|c}
\hline Date & $\begin{array}{c}\text { Number of bypass } \\
\text { sites (bridges } \\
\text { and culverts) }\end{array}$ & $\begin{array}{c}\text { Measured } \\
\text { discharge } \\
\left(\mathrm{ft}^{3} / \mathrm{s}\right)\end{array}$ \\
\hline$\underline{1972}$ & & \\
\hline Mar. 4 & 0 & 17.8 \\
Mar. 11 & 1 & 182 \\
Mar. 18 & 7 & 302 \\
Mar. 31 & 6 & 156 \\
Apr. 6 & 5 & 152 \\
\hline Apr. 19 3 & 12 & 37.2 \\
May 313 & 3 & 21.9 \\
May 13 & 4 & 9.9 \\
May 19 & 2 & 1.9 \\
June 2 & 2 & .38 \\
\hline June 15 & 1 & 0 \\
June 28 & 1 & \\
July 12 & 0 & \\
\hline
\end{tabular}

Flow of the Silvies River during the study period compared to the longterm average.--In using the flow data collected during the study period, the relationship of runoff during the study to the long-term average should be considered. The U.S. Geological Survey has published records for a streamgaging station on the Silvies River near Burns for 60 years (1903-5, 1909-12, 1917-21, 1922-73). Because of large-scale irrigation diversion, the records for Silvies River near Burns cannot be used directly in determining the volume of flow reaching the lake from the Silvies River basin, but they can be used as an index to the magnitude of the runoff in the basin. Using this gaging station as an index, figure 4 illustrates that the runoff from the Silvies was well above average during the 1972 water year, 162,000 acre-feet $\left(200 \mathrm{hm}^{3}\right)$ compared to the 60 -year average of 118,000 acre-feet $\left(150 \mathrm{hm}^{3}\right)$. Flow was well below average in the 1973 water year, 51,000 acre-feet $\left(62 \mathrm{hm}^{3}\right)$ compared to the 60-year average of 118,000 acre-feet $\left(150 \mathrm{hm}^{3}\right)$. Average flow for water years 1972 and 1973 was about 90 percent of the long-term average annual flow.

Effects on flow of upstream management practices.--Presently, the only management practice that significantly affects the volume of flow reaching the lake is irrigation. The U.S. Department of Agriculture (1967) reported that there are 122,700 acres $\left(497 \mathrm{~km}^{2}\right)$ of cropland irrigated from streamflow sources in the Silvies River basin.

Most of the streamflow from the basin is diverted for irrigation before it reaches Malheur Lake. In years of very low snowpack, all the flow is diverted and used before it reaches the lake, but in years of above-normal 


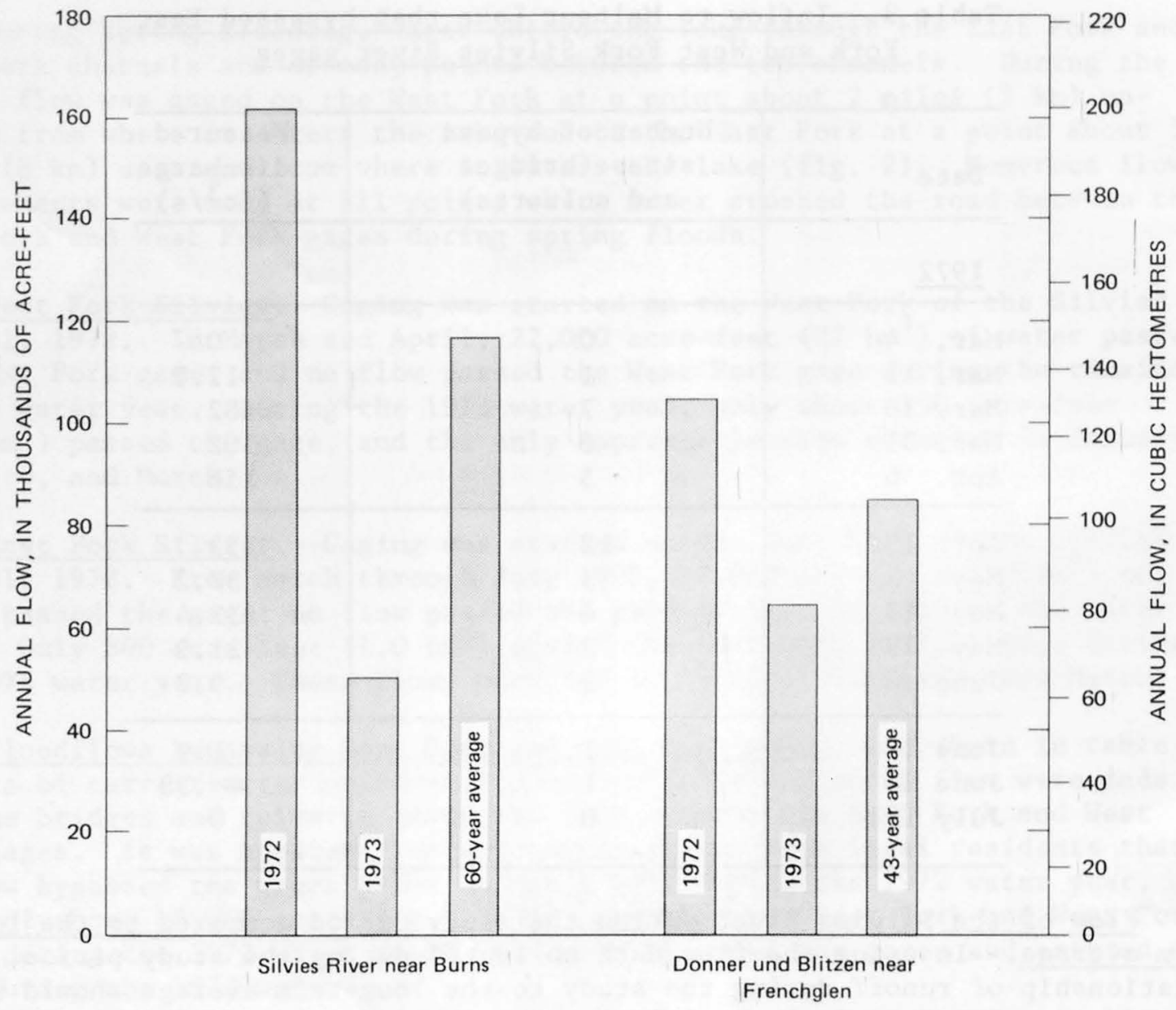

Figure 4 - Relationship of flow in Silvies River near Burns and the flow in Donner und Blitzen River near Frenchglen during 1972 and 1973 water years to the long-term average flow.

precipitation, such as the 1972 water year, about one-third of the runoff reaches the lake.

The drainage area of Silvies River near Burns gaging station is 934 square miles $\left(2,420 \mathrm{~km}^{2}\right)$. This is about three-fourths of its drainage area where it enters the lake. Much less flow enters the lake than passes the upstream gaging station, as shown in figure 5. In the 1972 water year, 162,000 acre-feet $\left(200 \mathrm{hm}^{3}\right)$ passed the upstream gage and only 55,000 acre-feet $\left(68 \mathrm{hm}^{3}\right)$ reached the lake. In the 1973 water year, 51,000 acre-feet $\left(63 \mathrm{hm}^{3}\right)$ passed the upstream gage and only 1,000 acre-feet $\left(1 \mathrm{hm}^{3}\right)$ flows into Malheur Lake. 


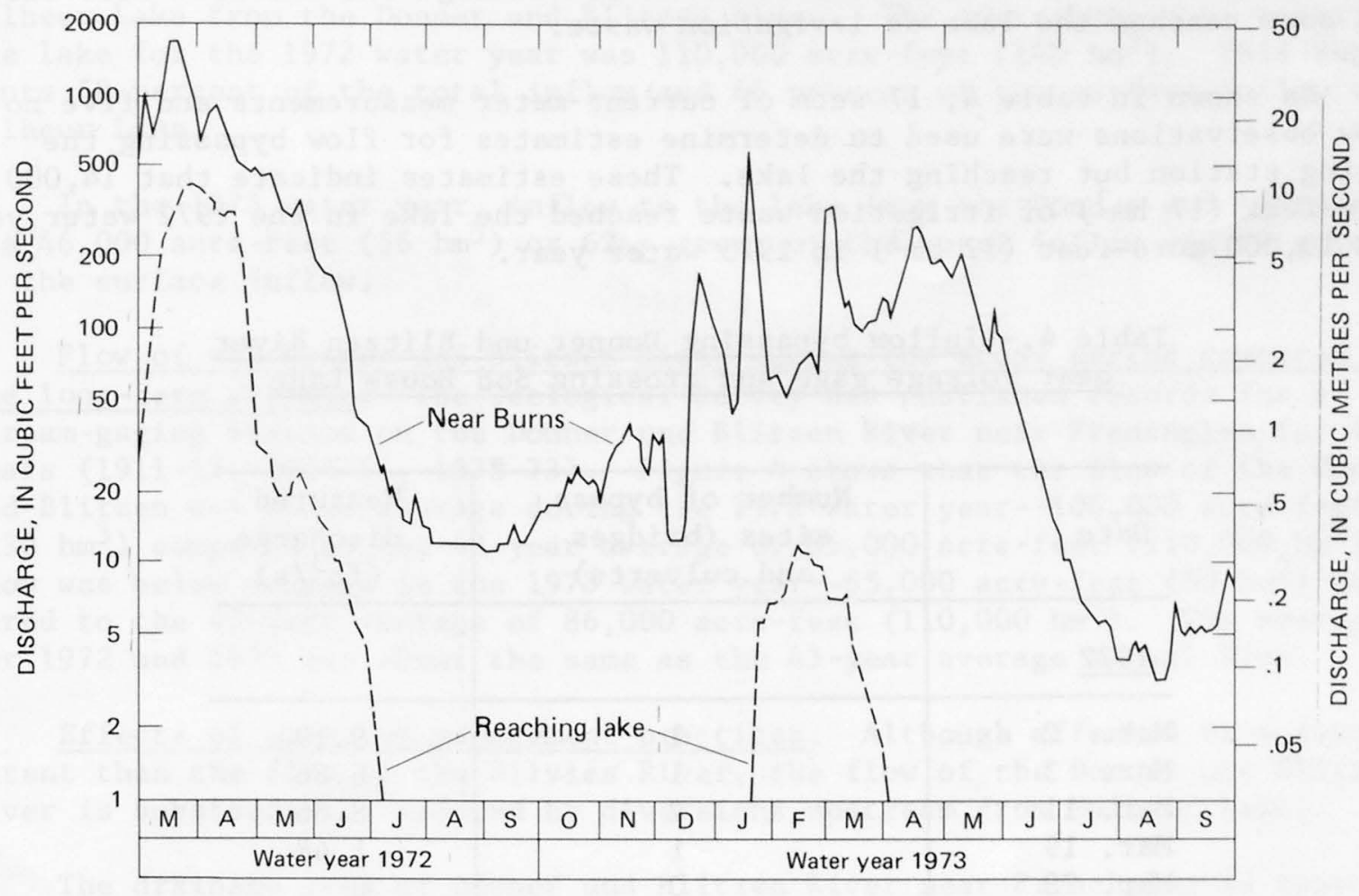

Figure 5 - Hydrographs for the Silvies River comparing flows passing the gaging station near Burns with flows reaching Malheur Lake.

\section{Donner und Blitzen River}

The Donner und Blitzen River, known locally as the "Blitzen," is the largest source of inflow to Malheur Lake. Its major source of water is from snowmelt on Steens Mountain. It has a drainage area of about 760 square miles $\left(2,000 \mathrm{~km}^{2}\right)$ and a main channel length of about $70 \mathrm{miles}(110 \mathrm{~km})$. Its basin ranges in elevation from 4,090 feet $(1,250 \mathrm{~m})$ at Malheur Lake to 9,670 feet $(2,950 \mathrm{~m})$ at a summit in Steens Mountain. Channel slope on Steens Mountain above Fish Creek at river mile $48(77 \mathrm{~km})$ is 100 feet per mile $(20 \mathrm{~m} / \mathrm{km})$; channel slope below Fish Creek in the Blitzen Valley is less than 10 feet per mile $(2 \mathrm{~m} / \mathrm{km})$. Just south of Malheur Lake, the slope is less than 2 feet per mile $(0.4 \mathrm{~m} / \mathrm{km})$. The upper part of the drainage area is covered with native grass and scattered juniper and aspen. The lower part consists of rangeland, some irrigated cropland, and artificial ponds and meadows established for wildlife habitat.

Gaging station Donner und Blitzen River near Voltage was reestablished for this study and is about 2 miles $(3 \mathrm{~km}$ ) upstream from Malheur Lake and just downstream from Sod House Dam. Water is diverted at and above Sod House Dam for irrigation. Most of this diverted water is used consumptively by 
vegetation, some infiltrates the alluvium to recharge the shallow water tabl and some reaches the lake as irrigation waste.

As shown in table 4, 17 sets of current-meter measurements and five noflow observations were used to determine estimates for flow bypassing the gaging station but reaching the lake. These estimates indicate that 14,000 acre-feet $\left(17 \mathrm{hm}^{3}\right)$ of irrigation waste reached the lake in the 1972 water year and 10,000 acre-feet $\left(12 \mathrm{hm}^{3}\right)$ in 1973 water year.

Table 4.--Inflow bypassing Donner und Blitzen River near Voltage gage and crossing Sod House Lane

\begin{tabular}{|c|c|c|}
\hline Date & $\begin{array}{c}\text { Number of bypass } \\
\text { sites (bridges } \\
\text { and culverts) }\end{array}$ & $\begin{array}{l}\text { Measured } \\
\text { discharge } \\
\left(\mathrm{ft}^{3} / \mathrm{s}\right)\end{array}$ \\
\hline \multicolumn{3}{|l|}{$\underline{1972}$} \\
\hline $\begin{array}{lr}\text { Mar. } & 2 \\
\text { Mar. } & 3 \\
\text { Mar. } 11 \\
\text { Mar. } 19 \\
\text { Mar. } 28\end{array}$ & $\begin{array}{l}1 \\
1 \\
2 \\
1 \\
0\end{array}$ & $\begin{array}{l}9.19 \\
6.86 \\
8.56 \\
1.48 \\
0\end{array}$ \\
\hline $\begin{array}{lr}\text { Apr. } & 20 \\
\text { May } & 2 \\
\text { May } & 12 \\
\text { May } & 17 \\
\text { June } & 1\end{array}$ & $\begin{array}{r}1 \\
8 \\
6 \\
12 \\
12\end{array}$ & $\begin{array}{l}13.8 \\
24.8 \\
114 \\
156 \\
155\end{array}$ \\
\hline $\begin{array}{ll}\text { June } & 14 \\
\text { June } & 28 \\
\text { July } & 12 \\
\text { July } & 26\end{array}$ & $\begin{array}{r}10 \\
7 \\
1 \\
0\end{array}$ & $\begin{array}{r}124 \\
50.3 \\
1 \text { (est.) } \\
0\end{array}$ \\
\hline \multicolumn{3}{|l|}{1973} \\
\hline $\begin{array}{lr}\text { Mar. } & 21 \\
\text { Apr. } & 5 \\
\text { Apr. } & 17 \\
\text { May } & 1 \\
\text { May } & 17\end{array}$ & $\begin{array}{r}0 \\
0 \\
2 \\
13 \\
15\end{array}$ & $\begin{array}{c}0 \\
0 \\
.6 \\
76.6 \\
115\end{array}$ \\
\hline $\begin{array}{ll}\text { May } & 30 \\
\text { June } & 13 \\
\text { June } & 27\end{array}$ & $\begin{array}{r}13 \\
14 \\
0\end{array}$ & $\begin{array}{c}118 \\
23.3 \\
0\end{array}$ \\
\hline
\end{tabular}


During March through September 1972, 69,300 acre-feet $\left(85 \mathrm{hm}^{3}\right)$ entered Malheur Lake from the Donner und Blitzen River. The contribution of water to the lake for the 1972 water year was 110,000 acre-feet $\left(140 \mathrm{hm}^{3}\right)$. This represents 58 percent of the total inflow and 66 percent of the surface inflow to Malheur Lake.

In the 1973 water year, inflow to the lake from the Donner und Blitzen was 46,000 acre-feet $\left(56 \mathrm{hm}^{3}\right)$ or 62 percent of the total inflow and 98 percent of the surface inflow.

F1ow of the Donner und Blitzen River during the study period compared to the long-term average.--The Geological Survey has published records for a stream-gaging station on the Donner und Blitzen River near Frenchglen for 43 years (1911-13,1914-16, 1938-73). Figure 4 shows that the flow of the Donner und Blitzen was above average during the 1972 water year--106,000 acre-feet $\left(130 \mathrm{hm}^{3}\right)$ compared to the 43 -year average of 86,000 acre-feet $\left(110,000 \mathrm{hm}^{3}\right)$. Flow was below average in the 1973 water year--65,000 acre-feet $\left(80 \mathrm{hm}^{3}\right) \mathrm{com}-$ pared to the 43 -year average of 86,000 acre-feet $\left(110,000 \mathrm{hm}^{3}\right)$. The average for 1972 and 1973 was about the same as the 43-year average annual flow.

Effects of upstream management practices. Although affected to a lesser extent than the flow of the Silvies River, the flow of the Donner und Blitzen River is substantially reduced by diversions upstream from Malheur Lake.

The drainage area of Donner und Blitzen River near Frenchglen is approximately 200 square miles $\left(500 \mathrm{~km}^{2}\right.$ ) but increases to approximately 760 square miles $\left(2,000 \mathrm{~km}^{2}\right)$ where the river enters the lake. There are several significant streams entering the Donner und Blitzen below the Frenchglen gage, including Bridge Creek, with an average annual flow of 9,800 acre-feet (12 $\left.\mathrm{hm}^{3}\right)$; Krumbo Creek; and Kiger Creek. In 1972, 106,000 acre-feet (130 $\left.\mathrm{hm}^{3}\right)$ passed Donner und Blitzen River near Frenchglen gage, and 110,000 acre-feet $\left(140 \mathrm{hm}^{3}\right)$ of water reached the lake. In the 1973 water year, 65,000 acre-feet $\left(80 \mathrm{hm}^{3}\right)$ passed the upstream gage and 46,000 acre-feet $\left(57 \mathrm{hm}^{3}\right.$ ) reached the lake.

According to the U.S. Department of Agriculture (1967), 39,600 acres $\left(160 \mathrm{~km}^{2}\right)$ were irrigated from streams in the Donner und Blitzen River basin. Water is also diverted to maintain the wildlife marshes in the lower Donner und Blitzen Valley. It is stated in Refuge Leaflet 47-AR that "Most of the ponds and the meadows of the Blitzen Valley and Double-O are artificial and are regulated by a system of dikes, canals, and water control structures." The water supplied for this sytem is diverted from streams in the Donner und Blitzen River basin.

The hydrographs of flows passing the Frenchglen and Voltage gaging stations (fig. 6) illustrate the effect on flow of diversions between the two stations. The shaded area gives a general indication of the volume of diversions started early in April 1972 and lasted through the middle of July 1972. Heavy diversion activity started again late in March 1973 and lasted until late in September 1973. 


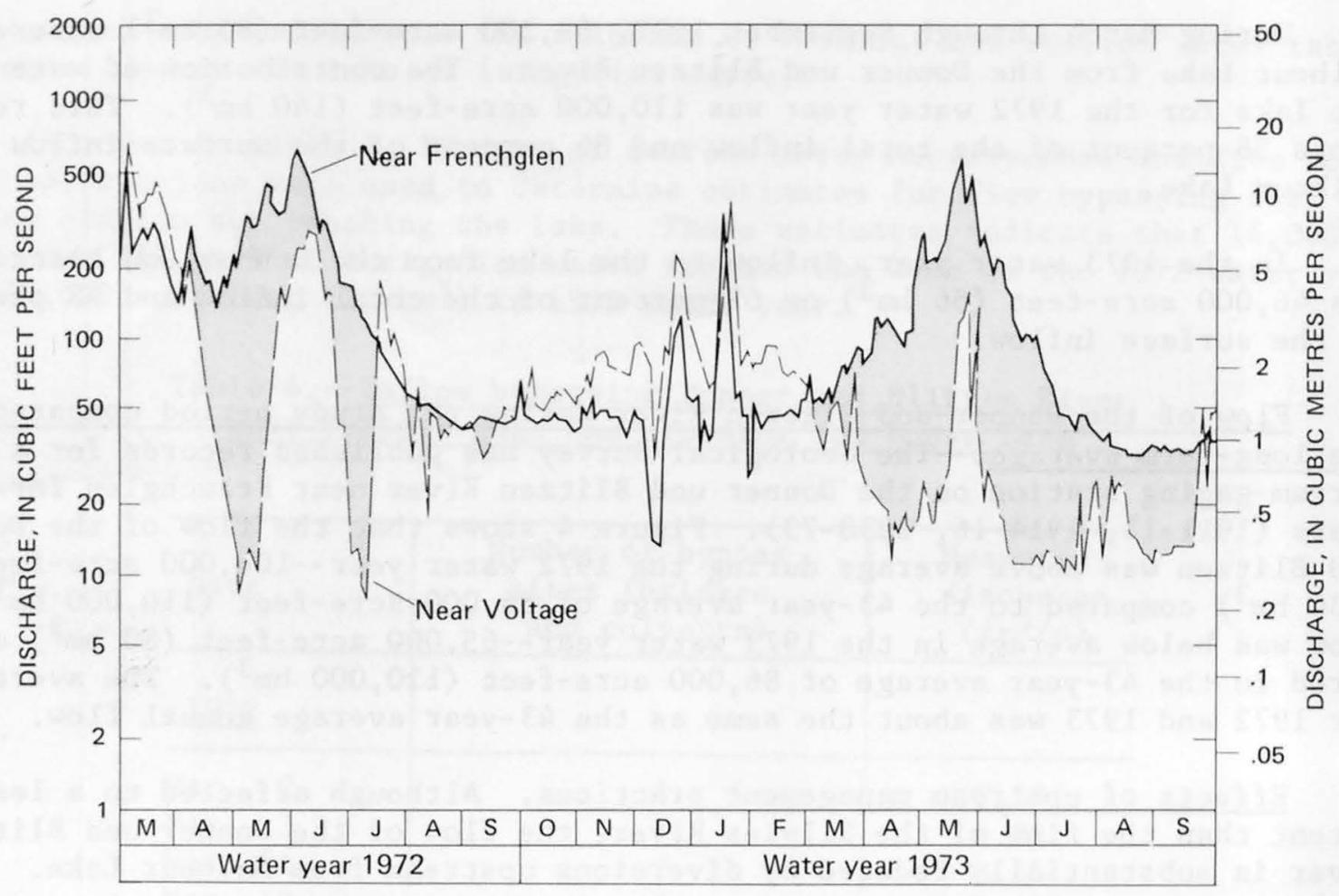

Figure 6 - Hydrographs of the Donner und Blitzen River comparing flows passing the Frenchglen gaging station with flows passing the Voltage gaging station. (The shaded area gives a general indication of the volume of diversion.)

It should be noted that the hydrograph shows the flow at the Voltage gaging station. This flow does not include that part of the irrigation flow that reaches the lake after being diverted above Sod House Dam. As stated before, the values shown in the water budget (tables 2 and 3 ) do include this irrigation waste that reaches the lake.

\section{Noncontributing Surface Drainages}

During this study, contribution of flow from Malheur Slough was neg1igible. As shown in table 5, flow was observed entering the lake on only 3 of 15 field inspections. The total volume of water entering the lake from Malheur Slough during this study was probably less than 50 acre-feet $\left(0.06 \mathrm{hm}^{3}\right)$ per year.

There are several noncontributing drainages on the north side of Malheur Lake; one of these is Poison Creek, a stream about 17 miles (27 km) 1ong, heading in Malheur National Forest and flowing southward to a flat area where it becomes Poison Creek Slough and continuing about 9 miles $(14 \mathrm{~km})$, where it disappears in cultivated fields about 10 miles (16 km) southeast of Burns. Other such noncontributing drainages on the north side of the lake are Prater, Soldier, Coffeepot, Rattlesnake, Cow, Big Rock, Curtis, and Crowcamp Creeks. 
Table 5.--Inflow to Ma1heur Lake from

Malheur Slough

\begin{tabular}{|c|c|}
\hline Date & $\begin{array}{c}\text { Measured } \\
\text { discharge } \\
\left(\mathrm{ft}^{3} / \mathrm{s}\right)\end{array}$ \\
\hline \multicolumn{2}{|l|}{1972} \\
\hline $\begin{array}{lr}\text { Mar. } & 11 \\
\text { Mar. } & 18 \\
\text { Mar. } & 31 \\
\text { Apr. } & 19 \\
\text { May } & 5 \\
\text { June } & 27\end{array}$ & $\begin{array}{l}0 \\
0 \\
0 \\
0 \\
0\end{array}$ \\
\hline \multicolumn{2}{|l|}{$\underline{1973}$} \\
\hline $\begin{array}{lr}\text { Jan. } & 10 \\
\text { Feb. } & 8 \\
\text { Mar. } & 6 \\
\text { Mar. } & 20 \\
\text { Apr. } & 4\end{array}$ & $\begin{array}{l}0 \\
0 \\
.1 \\
.01\end{array}$ \\
\hline $\begin{array}{lr}\text { Apr. } & 18 \\
\text { May } & 1 \\
\text { Sept. } & 25\end{array}$ & $\begin{array}{l}0 \\
0 \\
0\end{array}$ \\
\hline
\end{tabular}

On the south side of the lake, Riddle Creek drains off Steens Mountain and terminates in a small interior basin at Barton Lake and at Dry Lake Reservoir and does not reach Malheur Lake.

\section{Inflow from Direct Precipitation on the Lake Surface}

Precipitation records from the weather station at the Malheur National Wildlife Refuge Headquarters, along with daily water-surface areas determined during this study, were used to estimate the volume of precipitation falling directly on the lake's water surface.

During March 1972 through September 1972, 17,000 acre-feet (21 $\left.\mathrm{hm}^{3}\right)$ of water entered the lake by direct precipitation. From analysis of the additional weather records for October 1, 1971, to March 1972 and estimated lake areas, it is estimated that 27,000 acre-feet $\left(33 \mathrm{hm}^{3}\right)$ entered the lake from this source during the 1972 water year. This accounts for 14 percent of the total inflow for 1972. In the 1973 water year, 19,000 acre-feet $\left(23 \mathrm{hm}^{3}\right)$, which represents 25 percent of the total inflow, entered the lake as precipitation directly on the surface of the lake. 
Precipitation at the weather station was 8.30 inches $(21 \mathrm{~mm}$ ) in 1972 water year and 7.89 inches $(20 \mathrm{~mm})$ in 1973 water year. The average annua1 precipitation recorded at the weather station over the past 15 years is 8.97 inches $(23 \mathrm{~mm})$.

\section{Ground-Water Inflow}

Inflow from springs and from seepage through the lakebed from the groundwater table was considered in this study. Inflow from Sodhouse Spring was determined to be the only appreciable source of ground-water inflow to the lake, although some seepage from the shallow ground-water table may occur during periods of low lake level over a small area near the mouth of Donner und Blitzen River.

\section{Seepage into Lake from the Ground-Water Table}

The three shallow ground-water observation wells on a line from the north and perpendicular to the lake were monitored 23 times at fairly regular intervals during this study. The ground-water gradient was always away from the lake and was always 0.0005 or less. The three shallow wells on a line from the southeast were monitored 14 times, and the gradient was always away from the lake and very flat ( 0.0001 or less). The gradient along the line of we11s from the southwest (1ine C-C', fig. 7) was always toward the lake and ranged from 0.0001 to 0.0004 . However, the gradient from the lake surface to the ground-water level at the well closest to the lake was always away from the lake, except for those times when that part of the lakebed was dry. When the lakebed was dry along line $C_{-} C^{\prime}$, the water level at the well closest to the lake was lower than the bed of the lake.

The gradient from the lake surface to the well west of the lake was always away from the lake and averaged about 0.0004. (See 1ine D-D', fig. 7.) Figure 7 shows the ground-water profiles to the lake surface for a relatively high and relatively low lake stage. Because the lake is perched above the local water table over nearly all its area, water seeps into the lake from the shallow water table only from a small area along the south shore, and then only during periods of low lake level.

\section{Sodhouse Spring}

The area along the south side of the lake and extending south into the Donner und Blitzen River drainage basin is one of late volcanic lava flows and cinders. Several large-yielding irrigation wells tap a regional ground-water body in these rocks, from which springs issue near the mouth of the river. Smal1 quantities of water also flow from a few artesian wells near the edge of the lake.

Sodhouse Spring is the largest of the springs issuing from the volcanic rock, and it contributes the only measurable ground-water inflow to the lake. The other springs and flowing wells contribute negligible amounts. In the 1972 water year, Sodhouse Spring contributed 8,000 acre-feet $\left(10 \mathrm{hm}^{3}\right)$ or 5 percent of the total inflow to Malheur Lake. In the relatively dry, 

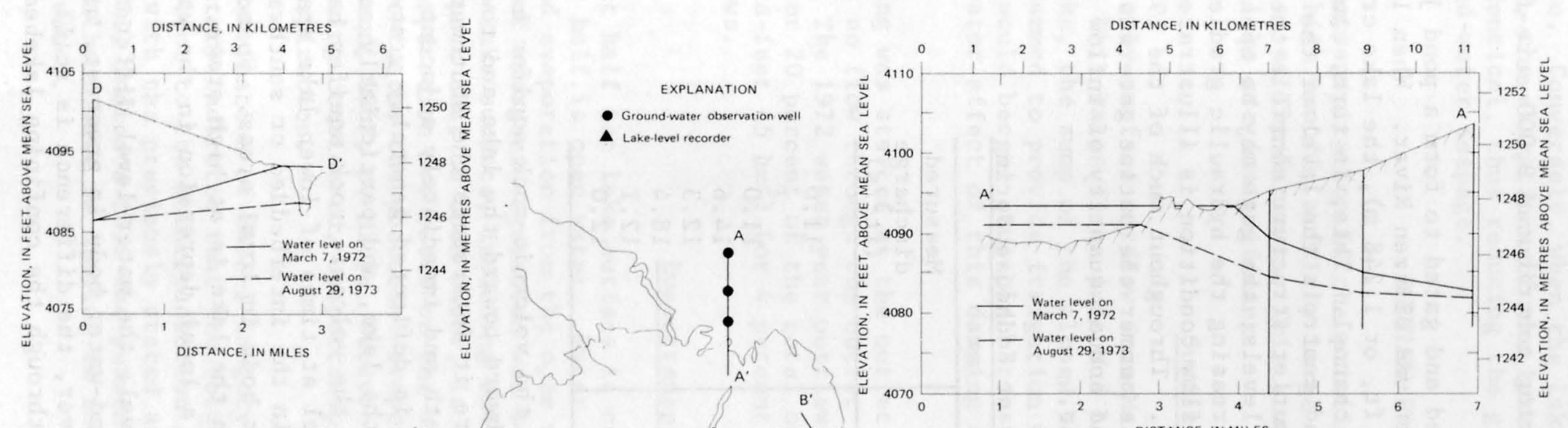

$\stackrel{N}{p}$

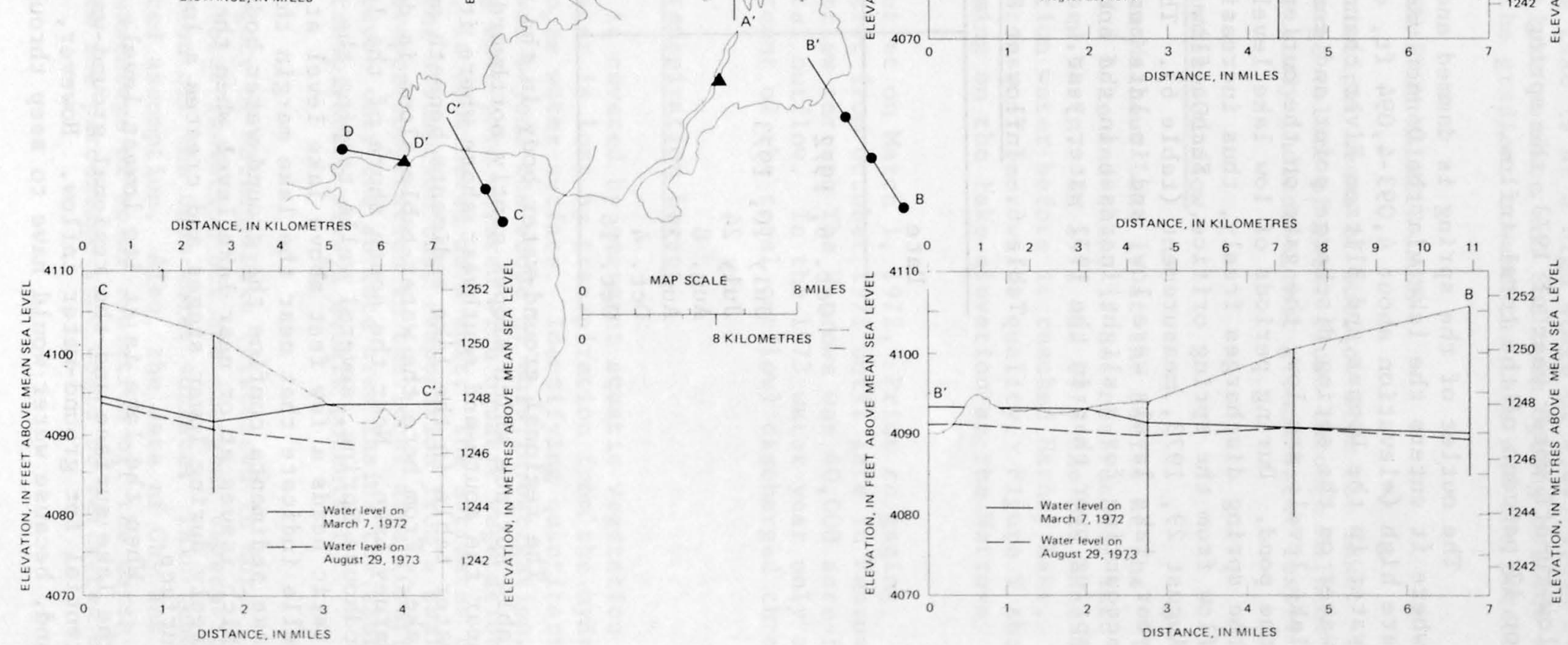

Figure 7 - Location of ground-water observation wells and schematic sections showing water-table profiles. 
low-runoff water year of 1973 , the spring contributed 9,000 acre-feet $\left(11 \mathrm{hm}^{3}\right)$ or 12 percent of the total inflow.

The outlet of the spring is dammed and gated to form a pond just above where it enters the lake via the Donner und Blitzen River. When lake stages are high (elevation about 4,093-4,094 ft, or 1,248 m), the lake creates backwater in the Donner und Blitzen River channel. This, in turn, causes backwater on the spring discharge point and controls the level of the pond. When lake levels are low, the gate on the outlet structure controls the level of the pond. During periods of low lake levels, the gate may be opened so that the spring discharges freely, thus increasing the hydraulic gradient and the flow from the spring orifice. Such a flow condition is illustrated by the August 29, 1973, measurement (table 6). Throughout much of the 1973 water year, lake levels were low, and in late summer the outlet gate was open, accounting for a slight increase in the annual quantity of inflow from the spring over that in the 1972 water year.

Table 6.--Inflow at Sodhouse Spring

\begin{tabular}{l|c}
\hline \multicolumn{1}{c|}{ Date } & $\begin{array}{c}\text { Measured } \\
\text { discharge } \\
\left(\mathrm{ft}^{3} / \mathrm{s}\right)\end{array}$ \\
\hline Oct. 6, 1972 & 11.0 \\
Ju1y 10, 1973 & 11.0 \\
Ju1y 24 & 14.6 \\
Aug. 8 & 12.3 \\
Aug. 29 & 18.4 \\
Oct. 4 & 12.1 \\
Oct. 16 & 12.0 \\
\hline
\end{tabular}

The regional ground-water body in the volcanic-rock aquifer has a watertable surface which slopes gently northward toward the lake and toward an area near the south and southwest shore where it intersects the southward-sloping water table in the lake sediments beneath and immediately adjacent to the lake. From here the water-table slope is deflected generally westward toward Harney Lake. Near the south shore of the lake, and parcicularly east of Sodhouse Spring, several wells tapping the volcanic-rock aquifer have hydrostatic heads a few feet above lake level at times of lower lake stages. These wells indicate that near the lake margin the interbedded or southward-1apping lake sediments confine the ground-water body in local areas. Sodhouse Spring, which issues at or near lake level when the lake is at high stage, discharges freely during lower stages and creates a local depression in the water-table surface.

When the lake is at its lowest level, the water-level difference between the lake surface and the regional ground-water body is greatest, as is the potential for ground-water inflow. However, the difference is still quite small and, because water would have to seep through the confining lakebed sediments 
which have very low permeabilities, the rate of seepage is considered to be negligible. Conversely, when the lake is at a high stage of 4,093-4,094 feet $(1,238 \mathrm{~m})$, the elevations of the lake surface and Sodhouse Spring orifice are nearly identical, thus reducing the gradient toward the lake and the potential for ground-water seepage.

\section{OUTFLOW FROM MALHEUR LAKE}

Evapotranspiration is the principal means of outflow from the lake. In years of high runoff, a fairly large volume of water flows through Malheur Lake outlet at The Narrows. This study indicates that ground-water losses from the lake are insignificant.

\section{Surface Outflow}

The only surface outflow from Malheur Lake is at the outlet at The Narrows. This water flows into Mud Lake and then, if not obstructed, into Harney Lake, the sump of the closed basin. In 1972 and 1973 the Mud Lake outlet was dammed to provide irrigation water before it reached Harney Lake, where it would become unusable because of poor water quality. Figure 9 shows the backwater effect of this damming on the lake elevation at the Narrows gage.

Gaging was started at the outlet on March 1, 1972. Prior to gaging, there was no flow through the outlet from October 1971 until late in February of 1972. The 1972 water year outflow through The Narrows was 40,000 acre-feet $\left(50 \mathrm{hm}^{3}\right)$ or 20 percent of the total outflow. In the 1973 water year only about 4,000 acre-feet $\left(5 \mathrm{hm}^{3}\right.$ ) (or 4 percent of the total outflow) discharged through The Narrows.

\section{Evapotranspiration Losses}

About half the lake surface is covered by emergent aquatic vegetation and the other half is open water. Water is lost by transpiration from the hydrophytes and evaporation from the open water surface. Identifying quantitatively the area of emergent vegetation was beyond the scope of this investigation. The total lake surface, including that part covered with aquatic vegetation and that part that is open water, is considered as a unit. The estimates of evapotranspiration are based on the assumption that evaporation from a shallow lake approximates the potential evapotranspiration in the local area (Cruff and Thompson, 1967, p. M26). Because only the surface area inside the shore1 ine is being considered, evapotranspiration always equals potential evapotranspiration.

An examination of ERTS-1 imagery of Malheur Lake (discussed in more detail later) indicates that the solar radiation off the emergent vegetation is equivalent to the solar radiation off the open-water surface. This tends to agree with the previously stated assumption. Also, the data of Gay and Holbo (1971) indicate that the percentage of solar radiation off the marsh area at Malheur Lake is similar to the percentage that would be reflected off the open water. 
During the second year of the study, pan evaporation was measured using a National Weather Service Class A land pan at the south edge of the lake at the Malheur National Wildlife Refuge Headquarters. The gage is maintained by refuge headquarters personnel. A regional coefficient of 0.74 (Kohler and others, 1959, p1. 3) was applied to the pan evaporation to obtain the lakesurface evaporation rate. To estimate evapotranspiration losses, the depth of evaporation was multipled by the surface area of the lake. Evaporation from the Refuge pan was compared with evaporation pan records for the Warm Springs Reservoir about 30 miles $(50 \mathrm{~km})$ northeast of Malheur Lake and for Malheur Experiment Station about 100 miles $(160 \mathrm{~km})$ to the northeast. The results of these comparisons were used to estimate the missing record at Malheur Lake. This includes the first year of this study, when the Malheur Lake evaporation pan was not in operation. Evapotranspiration is assumed to be negligible during winter because the lake is generally ice covered from December through much of March.

Monthly estimates of evapotranspiration are considered to be rather gross, although yearly estimates of evapotranspiration are considered to be quite reliable. Evapotranspiration accounts for by far the largest outflow of water from Malheur Lake (80 percent during the 1972 water year and 96 percent during the 1973 water year).

The evapotranspiration estimated for this study is equivalent to about 40 inches $(1,000 \mathrm{~mm})$ per year.

\section{Ground-Water Outflow}

The ground-water profiles (fig. 7) and the ground-water-1evel gradients measured during this study indicate that the lake is losing water by seepage; however, because of the low gradients and the extremely low permeability of the deposits underlying the lakebed, the loss to ground water is considered to be insignificant. To obtain data on permeability of the lakebed sediments, two samples from the lakebed were analyzed at the Geological Survey Hydrologic Laboratory in Denver, Colo. One sample, taken at 2- to 3-foot (0.5-1-m) depth, was silt with a median grain size of 7 micrometres. Another sample, from the 15- to 20-foot (4.5-6-m) depth, was a silty clay with a median grain size of 2 micrometres. Material of this size has an extremely low permeability, and sediments of essentially identical grain-size distribution from other areas have calculated hydraulic conductivities of about $10^{-4}$ metres/day. Consequently, it does not appear likely that significant quantities of water are lost from the lake by seepage through the lakebed sediments.

There has been conjecture (Phillips and Van Denburgh, 1971) that there may be leakage of water into the "peat bogs" at the north edge of the lake. Statements about this leakage refer to Piper, Robinson, and Park (1939, p. 30). Piper, Robinson, and Park mentioned peat beds about 2 feet $(0.6 \mathrm{~m})$ thick on the north and south margins of the lake and indicated that the peat is underlain by fine detrital sediments. They did not mention any deep peat bogs at Malheur Lake nor water losses to peat bogs. In any case, the peat (or muck which is more decomposed and consolidated than peat) layer is thin 
and is underlain by a silty clay of very low permeability. Statements by Piper, Robinson, and Park (1939) and data collected for this study do not indicate any consequential loss of water by seepage to peat bogs. Data obtained during this study indicate that losses from the lake to ground water are insignificant, probably less than 500 acre-feet $\left(0.6 \mathrm{hm}^{3}\right)$ per year.

\section{CHANGE IN LAKE CONTENTS}

Changes in lake contents were determined by months. Lake water-surface elevations were monitored, and surface areas were computed from data provided by aerial photography and ERTS-1. A relationship between stage and lakesurface area was developed from these data. To determine the monthly change in contents, changes in month-end water-surface elevations and lake watersurface areas were applied to the end-area formula.

\section{Lake Water-Surface Elevations}

Because of the complex geometry of the lake and lakebed, water levels are not equal at all points on the lake. Lake levels were monitored at five different locations on Malheur Lake (fig. 8). Analysis of the records from the lake-level gages indicates that the record for the gage at the break in Cole Island Dike is the most representative of the water level of the main body of the lake.

Duebbert (1969, p. 7) defined three distinct ecological units on Malheur Lake. One unit lies between The Narrows at the west end of the lake and a north-south ridge, Graves Point. Another unit lies between the north-south ridges of Graves Point and Cole Island Dike, and a third unit is east of Cole Island Dike. Data collected for this study indicate that these same boundaries define three distinct hydraulic units.

The unit bounded by Graves Point and Cole Island Dike (central unit, fig. 8 ) is the main body of the lake. That unit receives water directly from the Donner und Blitzen River and from the East and West Forks of the Silvies River. It has the deepest water in the lake and is the last part of the lake to go dry during extreme droughts. Of the five gages used during this study, the gage at the break in Cole Island Dike (fig. 8, gage 3) best represented the water level for this unit.

When the water surface in the central unit reaches an elevation of about 4,091 feet $(1,247 \mathrm{~m})$, water starts to flow through the breaks in Cole Island Dike into the east unit. Subsequently, when the water level in the central unit recedes, water flows back out of the east unit into the main unit through the same breaks in the dike. It follows that when water is rising rapidly in the central unit, water-surface elevations are higher than in the east unit and, conversely, when the water levels are dropping rapidly in the central unit, its water levels are lower than in the east unit. When water levels are above 4,091 feet $(1,247 \mathrm{~m})$ and holding fairly steadily, the water-surface elevations will equalize between the central and east units. Data from gage 4 (fig. 8) represent the water level at the extreme upper end of the east unit. 


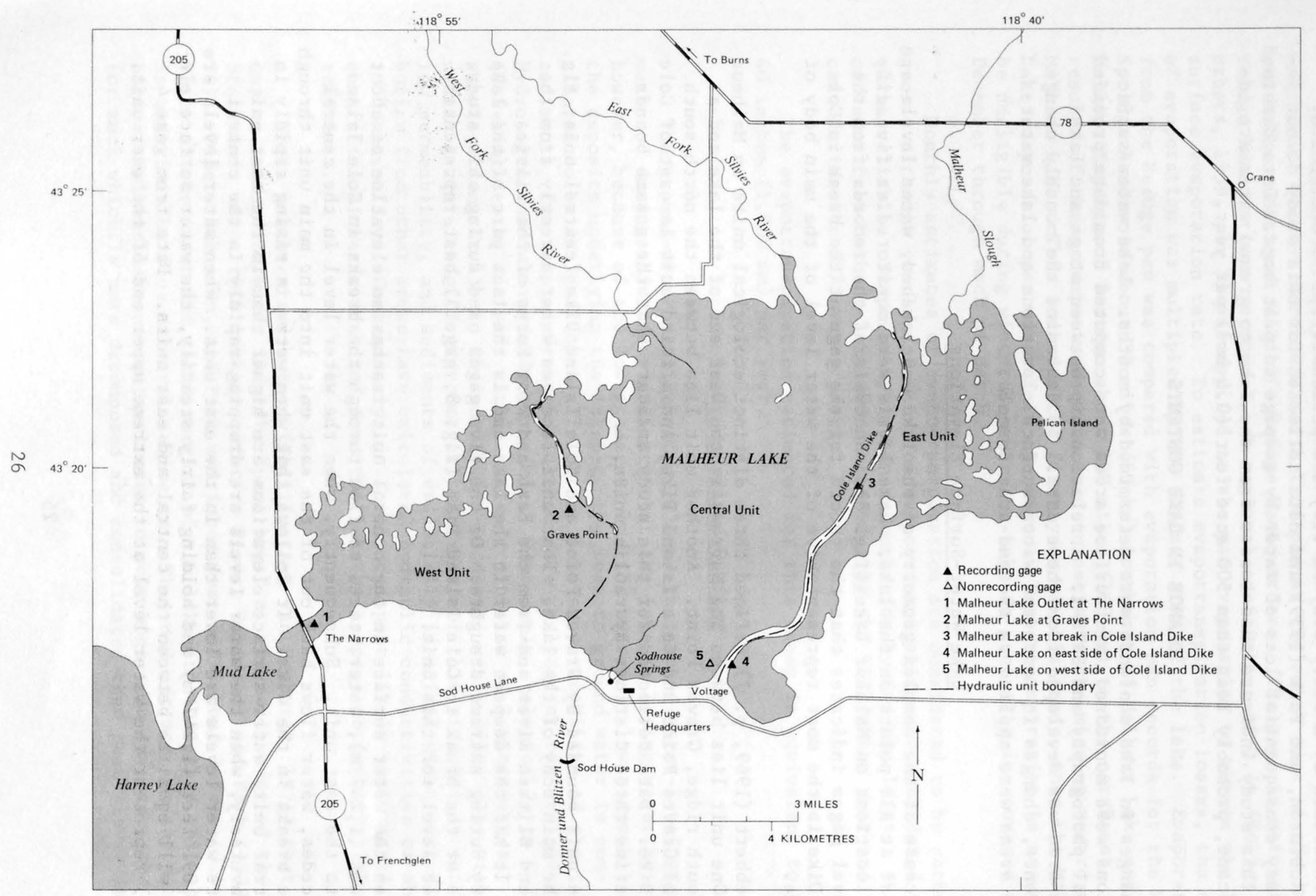

Figure 8 - Locations of water-level gaging sites and hydraulic units. 
Duebbert (1969, p. 8) described the unit to the west of Graves Point as "a series of ponds 10 to 500 acres ( 4 to $200 \mathrm{hm}^{2}$ ) in size, separated by a complex network of upland islands and peninsulas $* * *$." When the water-surface elevation in this unit reaches about 4,092 feet $(1,247 \mathrm{~m})$, water starts to move toward the outlet through this complex network of islands and peninsulas.

Data from the gage at Graves Point represent the water-surface elevation at the upper end of the west unit, and data from the outlet gage at The Narrows represent the water-surface elevation at the lower end. The watersurface profile between the two gages is not defined, but the topography indicates that it is irregular.

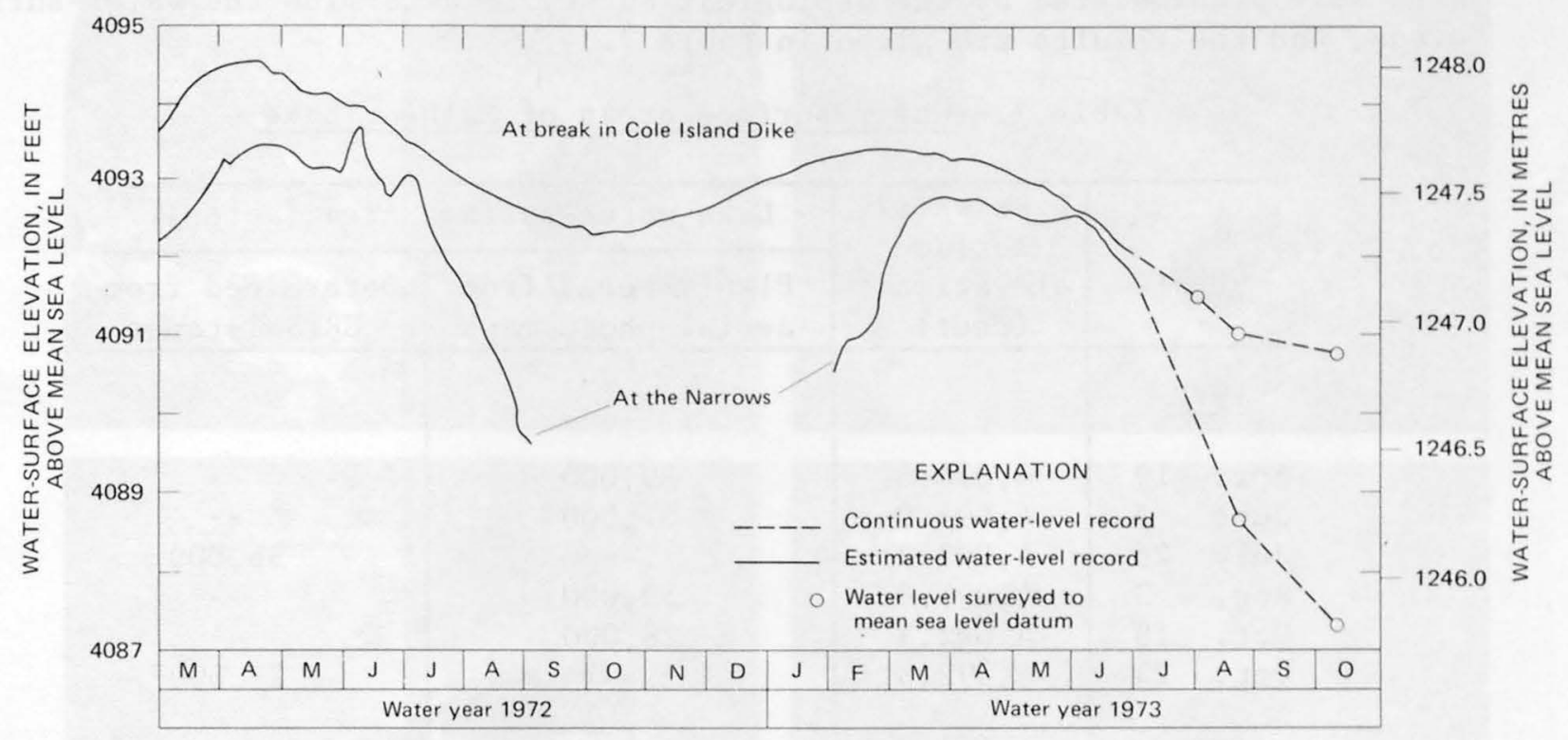

Figure 9 - Water-surface elevations of Malheur Lake at break in Cole Island Dike and Malheur Lake Outlet at The Narrows.

Hydrographs for the outlet at The Narrows and for the lake at the break in Cole Island Dike are shown in figure 9. A careful analysis of all the water-level records indicates that the water levels for the gage at the break in the dike and the gage at Graves Point are virtually the same when water levels are above 4,092 feet $(1,247 \mathrm{~m})$ elevation. Figure 9 shows two dis similarly shaped hydrographs. The reason for the different shapes is that The Narrows is separated from the main body of the lake by a topographic control that affects the hydraulic connection between The Narrows and the main body of the lake; also, the lake elevations at The Narrows are affected by events that occur downstream as well as upstream from the gage. The water level rises at The Narrows as water overflows from the main lake. Rises also occur at The Narrows when water is dammed downstream for irrigation use. The hydrograph shows two such rises, starting on June 4 and July 1, 1972. The stage record 
from the Narrows gage cannot be used to directly define the area or capacity of Malheur Lake.

\section{Determination of Lake Water-Surface Areas}

From March 1, 1972, through September 30, 1973, the water-surface elevation of the main body of the lake varied by only 3.5 feet $(1 \mathrm{~m})$, whereas the surface area of the lake ranged from 15,000 to 62,000 acres $(6,000$ to 25,000 $\mathrm{hm}^{2}$ ). Most of this range in water-surface area is demonstrated by the ERTS-1 imagery in figure 10 .

Four scale-accurate line maps of the water-surface boundaries of Malheur Lake were prepared by the Corps of Engineers, from aerial photography. These maps were planimetered by the Geological Survey to determine the water-surface areas, and the results are given in table 7 .

Table 7.--Water-surface areas of Malheur Lake

\begin{tabular}{|c|c|c|c|c|}
\hline \multirow{2}{*}{\multicolumn{2}{|c|}{ Date }} & \multirow{2}{*}{$\begin{array}{l}\text { Lake water- } \\
\text { surface } \\
\text { elevation } 1 / \\
\text { (feet) }\end{array}$} & \multicolumn{2}{|c|}{ Lake water-surface area (acres) } \\
\hline & & & $\begin{array}{l}\text { Planimetered from } \\
\text { aerial-photo maps }\end{array}$ & $\begin{array}{l}\text { Determined from } \\
\text { ERTS-1 tapes }\end{array}$ \\
\hline \multicolumn{5}{|l|}{$\underline{1972}$} \\
\hline Apr. & 19 & $4,094.6$ & 59,000 & -- \\
\hline June & 5 & $4,094.0$ & 57,000 & - \\
\hline July & 25 & $4,093.2$ & - & 36,000 \\
\hline Aug. & 3 & $4,093.0$ & 39,000 & -- \\
\hline Oct. & 18 & $4,092.3$ & 28,000 & -- \\
\hline Oct. & 23 & $4,092.3$ & -- & 27,000 \\
\hline \multicolumn{5}{|l|}{1973} \\
\hline Apr. & 3 & $4,093.3$ & - & 42,000 \\
\hline May & 9 & $4,093.0$ & - & 35,000 \\
\hline July & 2 & $4,092.2$ & -- & 24,000 \\
\hline July & 20 & $4,091.8$ & -- & 21,000 \\
\hline Aug. & 7 &, $1^{4,091.5}$ & -- & 19,000 \\
\hline Sept. & 13 & $\frac{2}{4}, 4,091.0$ & -- & 17,000 \\
\hline Oct. & 18 & $2 / 4,090.8$ & -- & 16,000 \\
\hline
\end{tabular}

1/ Elevations refer to center section of lake as gaged at break in Cole Island Dike.

2/ Lake levels estimated from water-level surveys shown in figure 9 . 

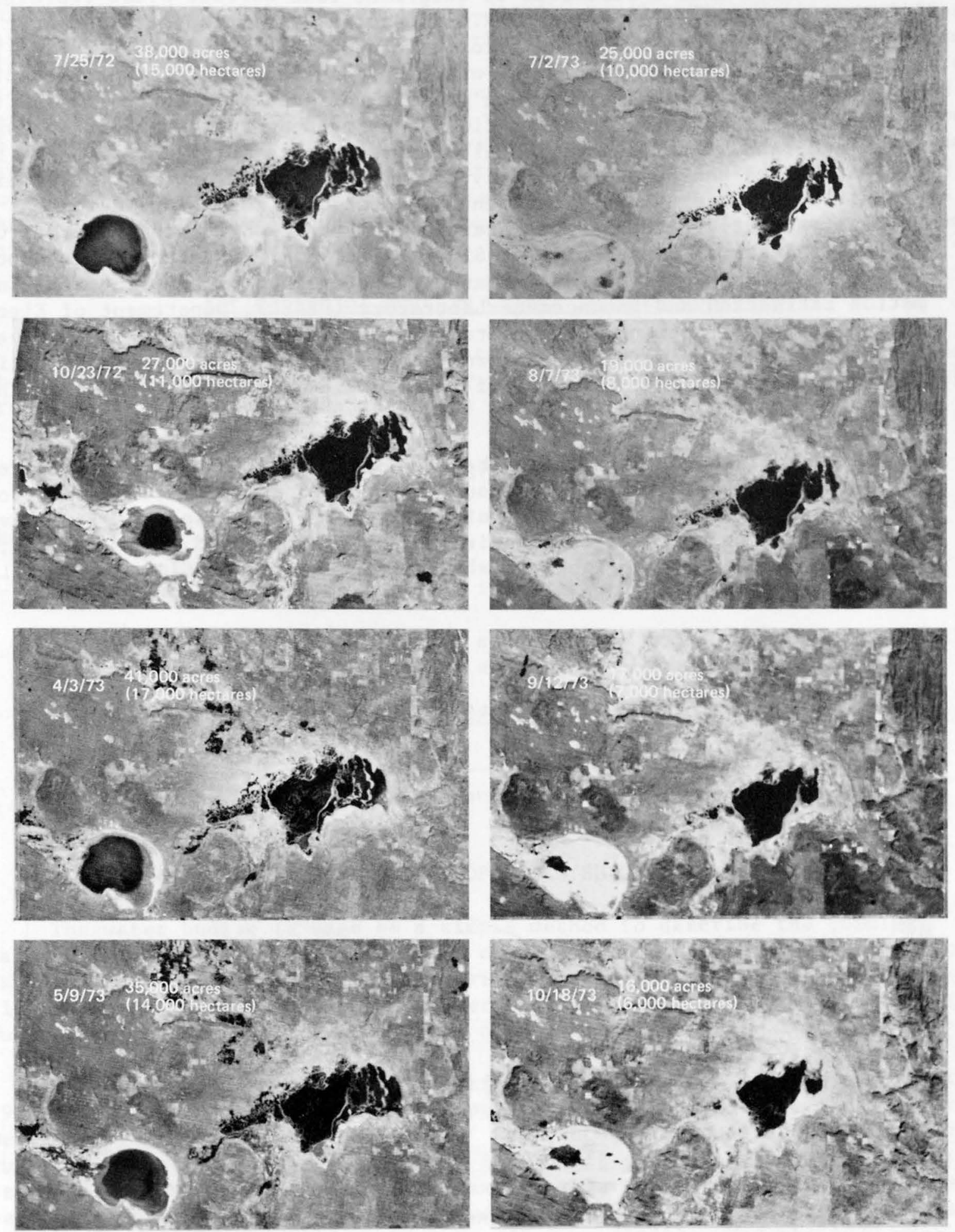

Figure 10 - ERTS-1 imagery showing water surface of Malheur Lake on different dates. 
Data from ERTS-1 were used to determine lake-surface areas representing nine water-surface elevations. ERTS-1 contains a multispectral scanner with sensors that measure solar radiation reflected from the earth. By utilizing an infrared band for a wavelength at which water absorbs most of the solar radiation and landforms cause much greater reflection, the ERTS-1 data (supplemented by ground-truth information) can be used to discriminate between water and land. Each resolution element represents 1.125 acres $\left(0.455 \mathrm{hm}^{2}\right)$. The water area can be determined by counting the number of resolution elements classified as water (Herzog and others, undated). The ERTS-1 data on computer-compatible tapes were obtained from the EROS (Earth Resources Observation Systems) Data Center at Sioux Falls, S.D. The tapes were processed and Malheur Lake water-surface areas were determined by the Pictoria1 Information Extraction and Enhancement Laboratory (PIXEL), Department of Electrical and Computer Engineering, Oregon State University. The Geological Survey provided PIXEL with ground-truth information to assist them in discriminating between water and land. Results of the area determinations are shown in table 7 .

Figure 11 shows the relation between lake elevation and surface area, based on the data in table 7. Because the relationship was developed for data obtained during the study, it is valid for that time period only. However, the relationship varies with changing inflow patterns and other factors; therefore, the curve in figure 11 should be used with caution, if at al1, for other time periods.

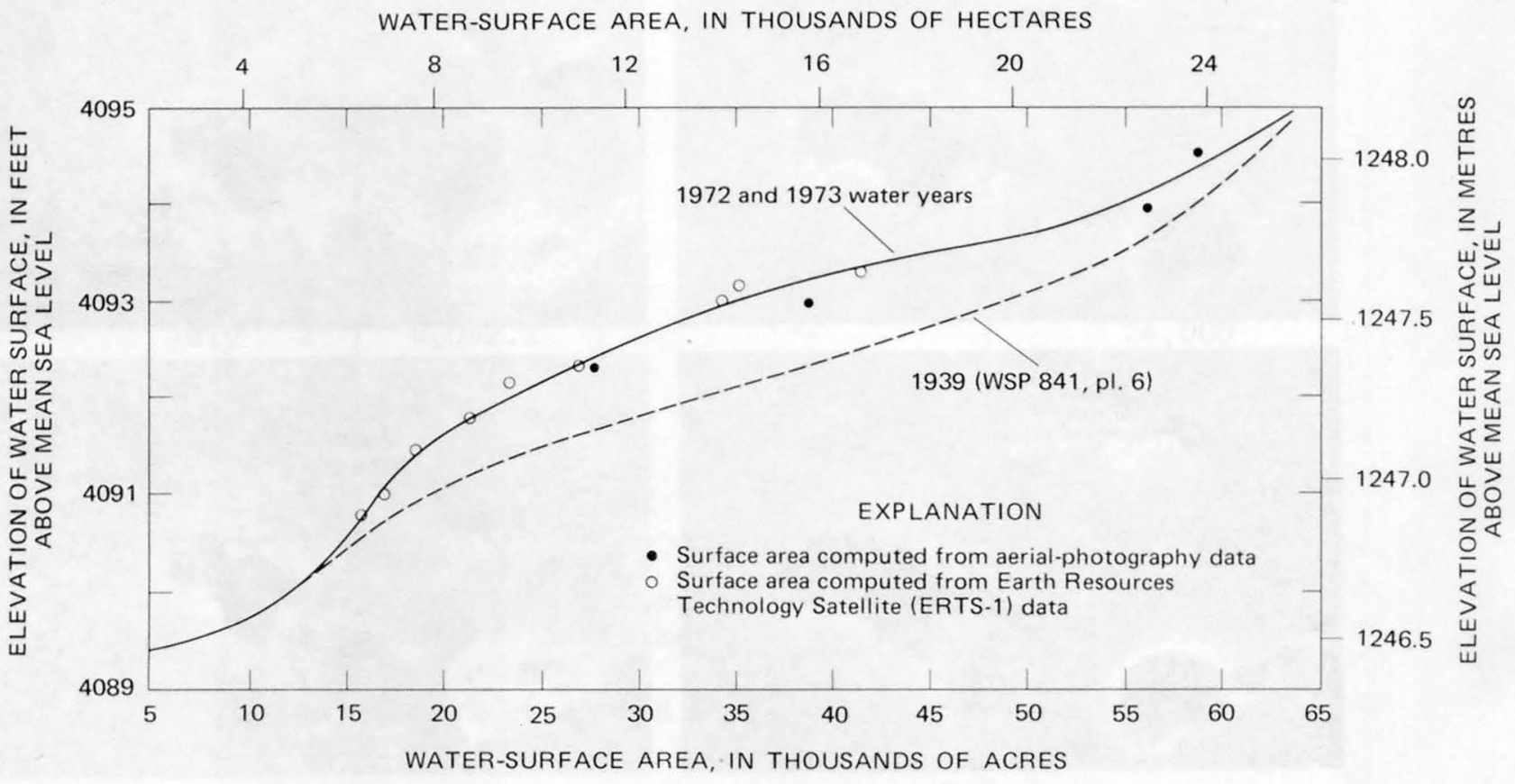

Figure 11 - Area curves of Malheur Lake. 
Also shown in figure 11 is a curve showing the lake level-area relationship used by Piper, Robinson, and Park (1939, p1. 6). The two curves differ, partly because of physical changes in the lake since 1939, but largely because different methods were used to develop them. For the present study, surface areas were determined directly, from aerial photographs or ERTS-1 data, and were related to corresponding observed water-surface levels for the main body of the lake. The curve used in the 1939 report was developed from a contour map made when the lakebed was nearly dry. The lake area used also included Mud Lake, and the lake surface was assumed to be at a uniform level for the entire lake area. As discussed previously, the lake-surface elevation is not uniform under most conditions.

\section{Estimation of Monthly Change in Lake Contents}

The month-end water-surface elevations for the main body of the lake and the water-surface areas represented by the elevations were applied to the endarea formula to estimate the change in volume of water for each month.

$$
\Delta v=\frac{1}{2} \Delta S\left(A_{1}+A_{2}\right)
$$

where

$$
\begin{aligned}
& \Delta V=\text { Change in contents of water, in acre-feet, for the month, } \\
& \Delta S=\text { Difference, in feet, in lake stage at the end of the previous month } \\
& \text { from the lake stage at the end of the month being estimated, } \\
& A_{1}=\text { Lake water-surface area, in acres, at the end of the previous month, } \\
& \text { and } \\
& A_{2}=\text { Lake water-surface area, in acres, at the end of the month being } \\
& \text { estimated. }
\end{aligned}
$$

\section{EVALUATION OF WATER BUDGET}

The water budget is used as a simple method to describe the complex Malheur Lake hydrologic system. Each component of the water-budget equation is a reliable estimate based on extensive data collection and analysis. The figures in the monthly and yearly water budgets describe the relative magnitude of inflow and outflow components of Malheur Lake.

The water budgets provide a quantitative description of the lake for the 1972 and 1973 water years. A much longer study period would be necessary to define average or extreme conditions. Even though 1972 was a relatively high runoff year and 1973 was a relatively low runoff year, they do not necessarily represent extreme conditions. For example, the runoff into Malheur Lake was wel1 below average in 1973 but there was an above-average carryover of water in the lake from the preceding high-runoff year (1972). Had the 1973 water year followed a drought year, the water budget would have been considerably different. 


\section{WATER QUALITY}

Analyses of water quality of miscellaneous samples taken at all inflow and outflow points and at eight points within the lake (fig. 12) are shown in tables 8 and 9 .

Some general statements about water quality can be based on these data. Inflows from the Donner und Blitzen River, both forks of the Silvies River, and Sodhouse Spring are all low in dissolved solids. Another factor contributing to the rather dilute nature of the lake water is that 25 percent of the total inflow in the low-runoff 1973 water year was from direct precipitation. As would be expected, evaporation causes the dissolved-solids concentration to increase as the elevation of the lake recedes.

The data show that the calcium concentration generally remains the same or decreases as dissolved solids increase, whereas sodium concentration increases, indicating ionic exchange with the sodium ion. The samples collected in June 1972 from the lake west of Cole Island Dike show a marked decrease in the silica concentration from earlier samples, most likely caused by an uptake by diatoms. Samples collected east of Cole Island Dike did not show a decrease in silica.

The chemical quality differs greatly from point to point in the lake as well as from time to time. These noticeable differences in water quality are largely a result of the hydraulics of the lake. Some examples of how the hydraulics affect the lake chemistry in this respect are:

1. The part of the lake east of Cole Island Dike is not flushed directly. Water does not flow through this part of the lake which fills through the breaks in the dike when the main body of the lake rises. When the water level in the main body of the lake recedes, this section drains out through these same breaks.

2. Peak inflows from the Silvies and the Donner und Blitzen Rivers do not occur at the same time. Also, the quality of water in the Donner und Blitzen River differs from that in the Silvies River, as shown in table 8 .

3. The Donner und Blitzen River provides water to the lake throughout the year, and the Silvies River provides water to the lake only during very high runoff periods.

4. The geometry of the lake and the vegetation in the lake create an erratic and ever-changing pattern of water movement through the lake.

5. At most times of the year, the part of the lake west of Graves Point is a maze of ponds, islands, and peninsulas rather than a single body of water. 


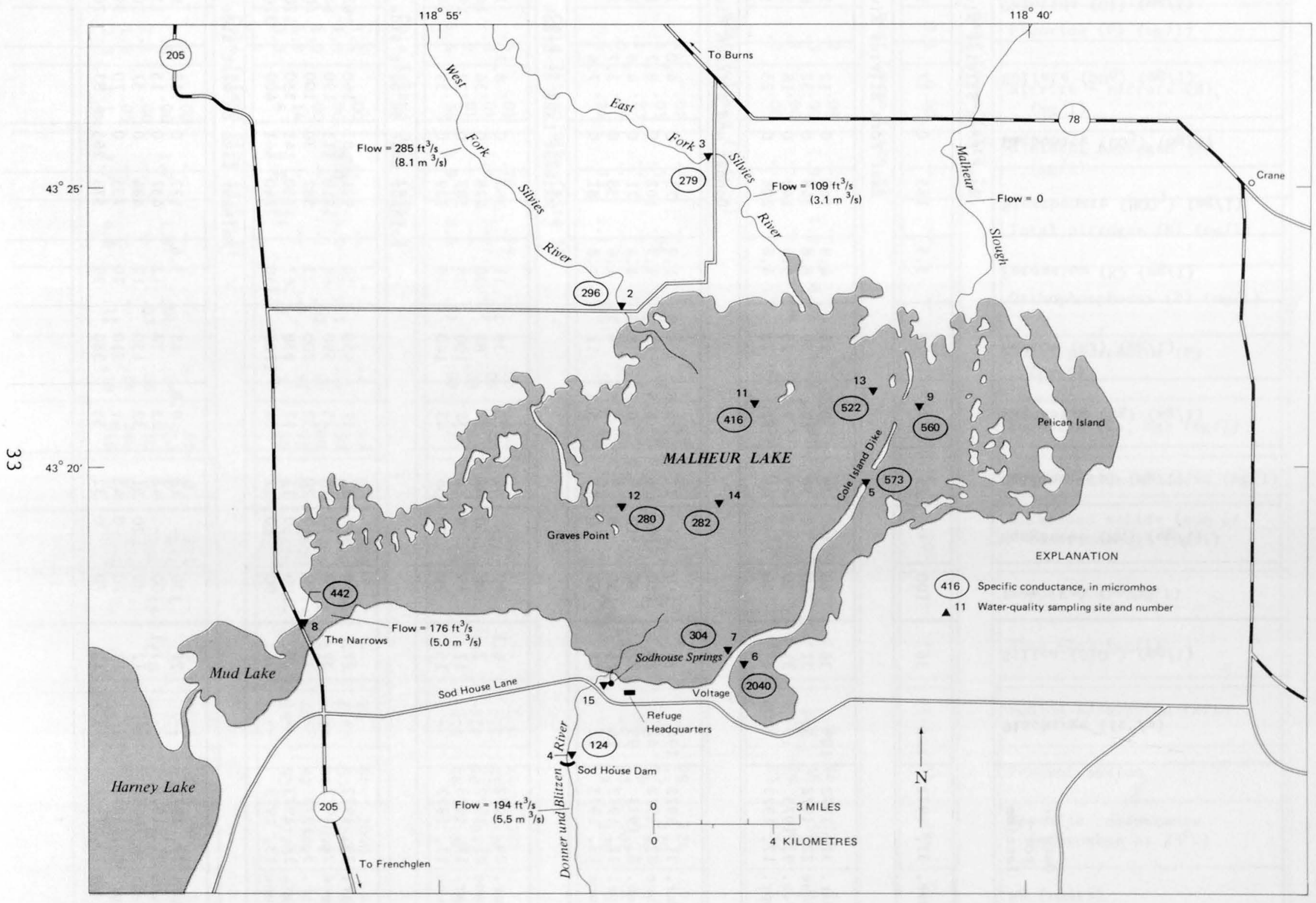

Figure 12 - Locations of water-quality sampling sites, and specific conductance and streamflow near the end of March 1972. 


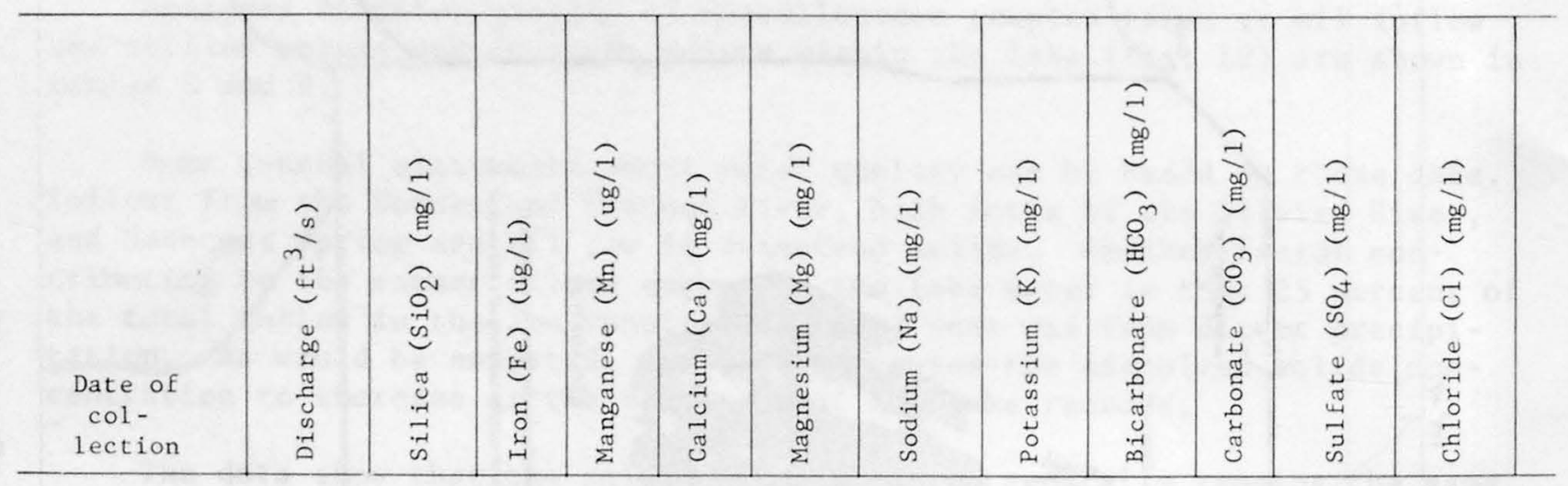

West Fork Silvies River

\begin{tabular}{|l|l|l|l|l|l|l|l|l|l|l|l|l|l|l|}
\hline Mar. 31, 1972 & 285 & 36 & 100 & - & 29 & 7.9 & 26 & 5.5 & 165 & 0 & 17 & 3.4 & \\
\hline
\end{tabular}

East Fork Silvies River

\begin{tabular}{l|c|c|c|r|r|r|r|r|r|r|r|r|r|}
\hline Mar. 31, 1972 & 109 & 36 & 70 & - & 29 & 8.2 & 18 & 4.9 & 160 & 0 & 12 & 2.7 & \\
June 22, 1972 & 5.4 & 31 & 40 & 0 & 50 & 16 & 59 & 8.8 & 349 & 0 & 32 & 8.3 & 16 \\
Feb. 9, 1973 & 10 & 31 & 50 & 10 & 26 & 7.7 & 15 & 3.4 & 149 & 0 & 18 & 3.1 \\
Apr. 17, 1973 & .06 & 27 & 50 & 0 & 41 & 11 & 23 & 4.8 & 206 & 0 & 25 \\
\hline
\end{tabular}

Donner und Blitzen River

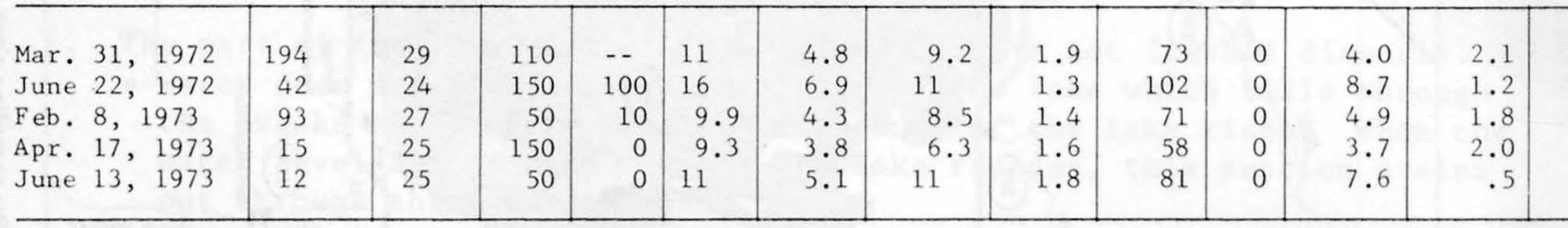

Malheur Lake at break in

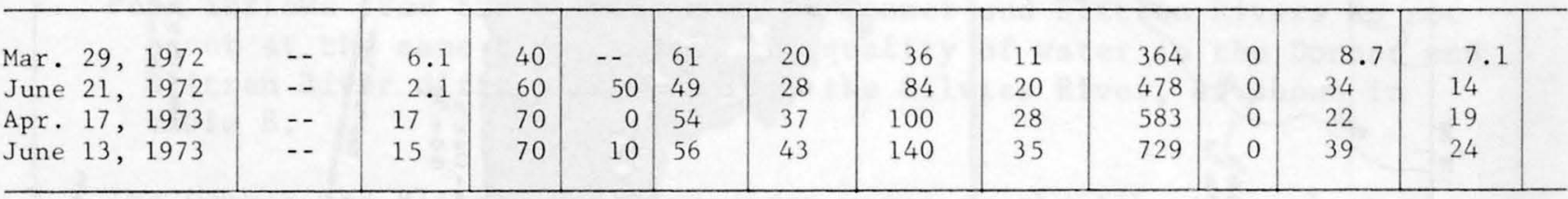

Malheur Lake on east side of

\begin{tabular}{|c|c|c|c|c|c|c|c|c|c|c|c|c|}
\hline Mar. 29, 1972 & - & 27 & 80 & - & 11 & 17 & 450 & 50 & 921 & 83 & 160 & 63 \\
\hline June 21, 1972 & - & 39 & 70 & 10 & 18 & 25 & 590 & 68 & 1410 & 113 & 190 & 84 \\
\hline Feb. 5, 1973 & - & 32 & 50 & 0 & 20 & 52 & 200 & 23 & 582 & 30 & 100 & 40 \\
\hline Apr. 17, 1973 & - & 29 & 100 & 0 & 11 & 17 & 950 & 67 & 1750 & 145 & 350 & 170 \\
\hline June 13, 1973 & - & 26 & 90 & 10 & 12 & 24 & 1700 & 130 & 2740 & 441 & 600 & 320 \\
\hline
\end{tabular}

Malheur Lake on west side of

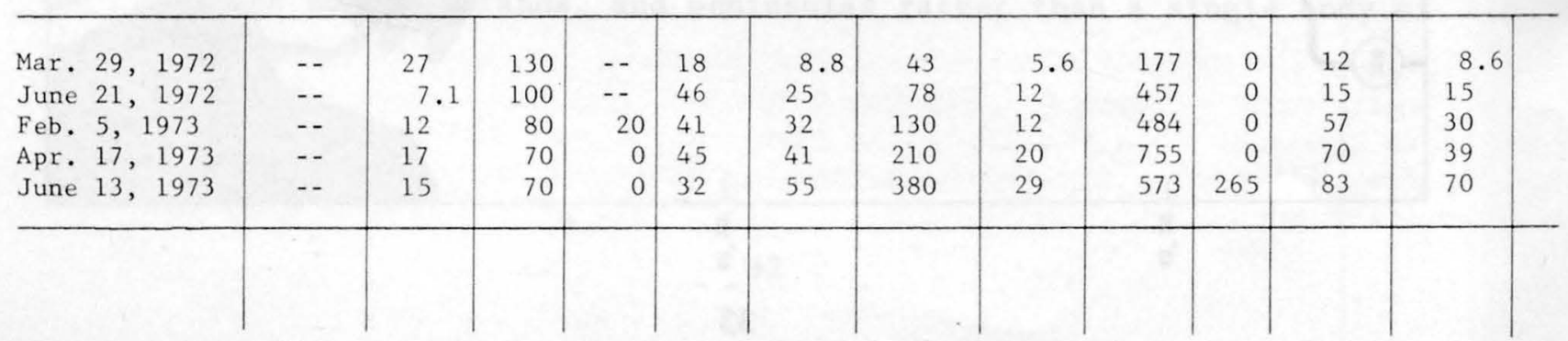




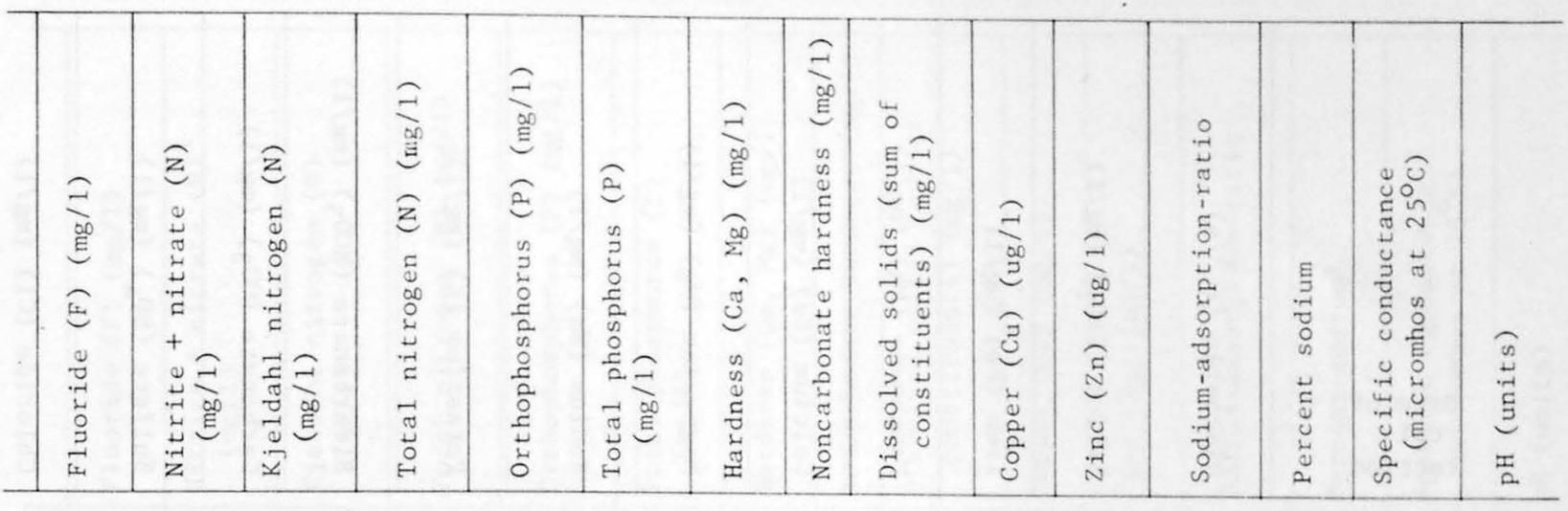

near Lawen (site 2)

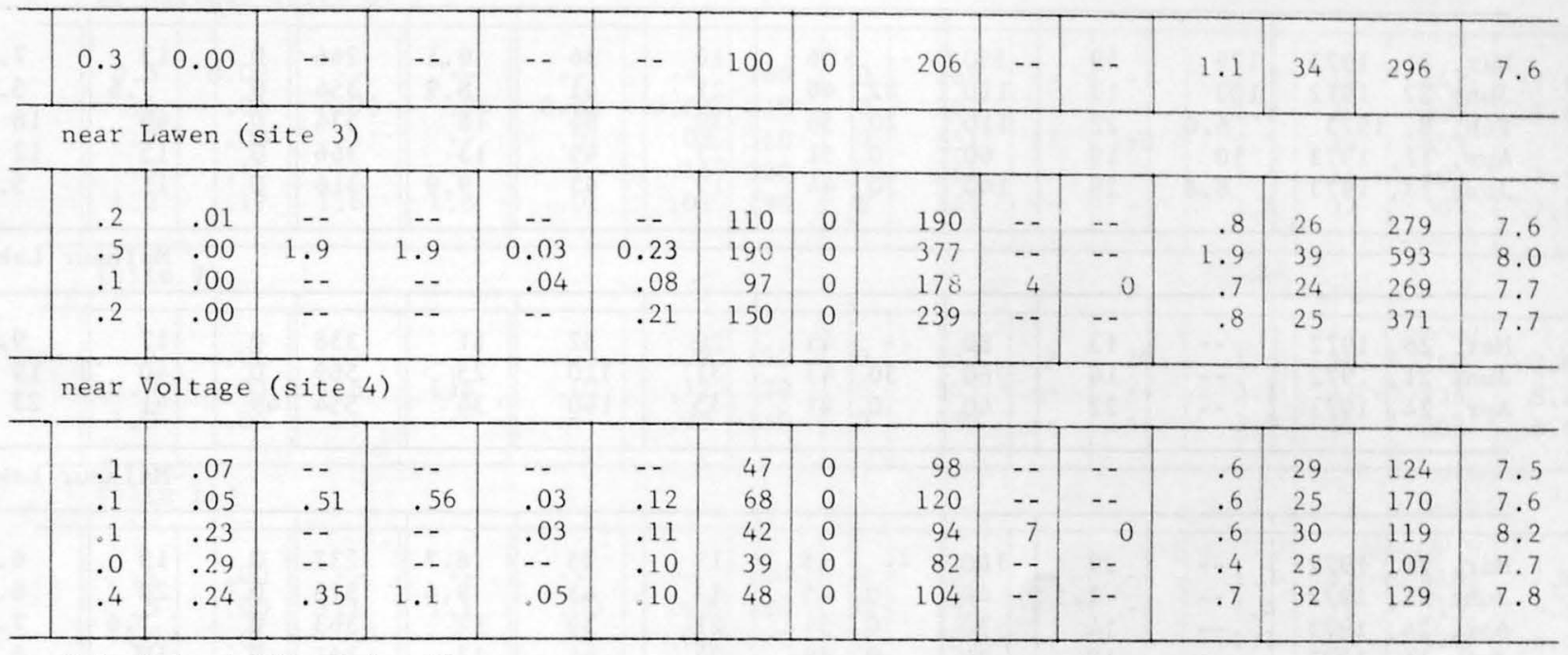

Cole Island Dike (site 5)

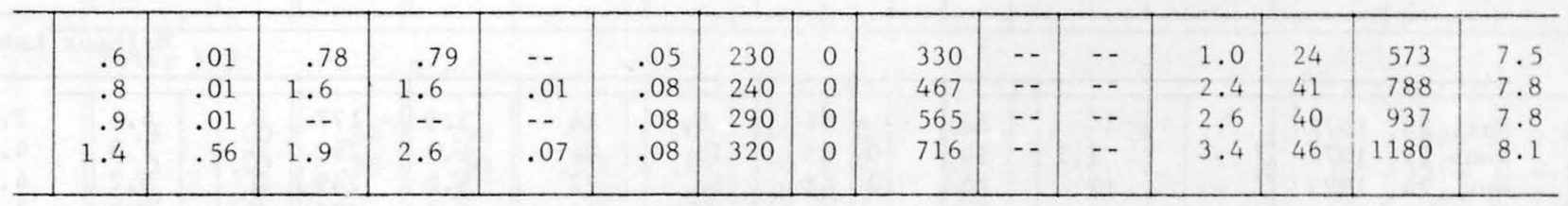

Cole Island Dike (site 6)

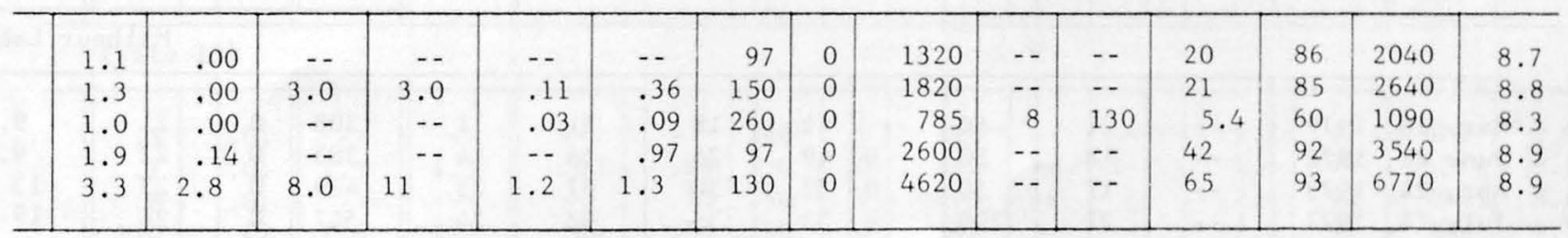

Cole Island Dike (site 7)

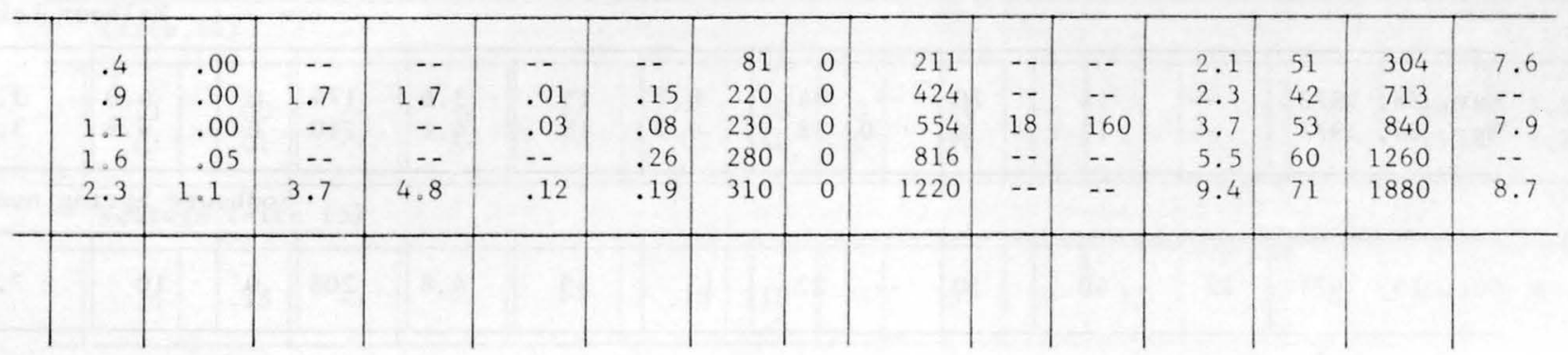




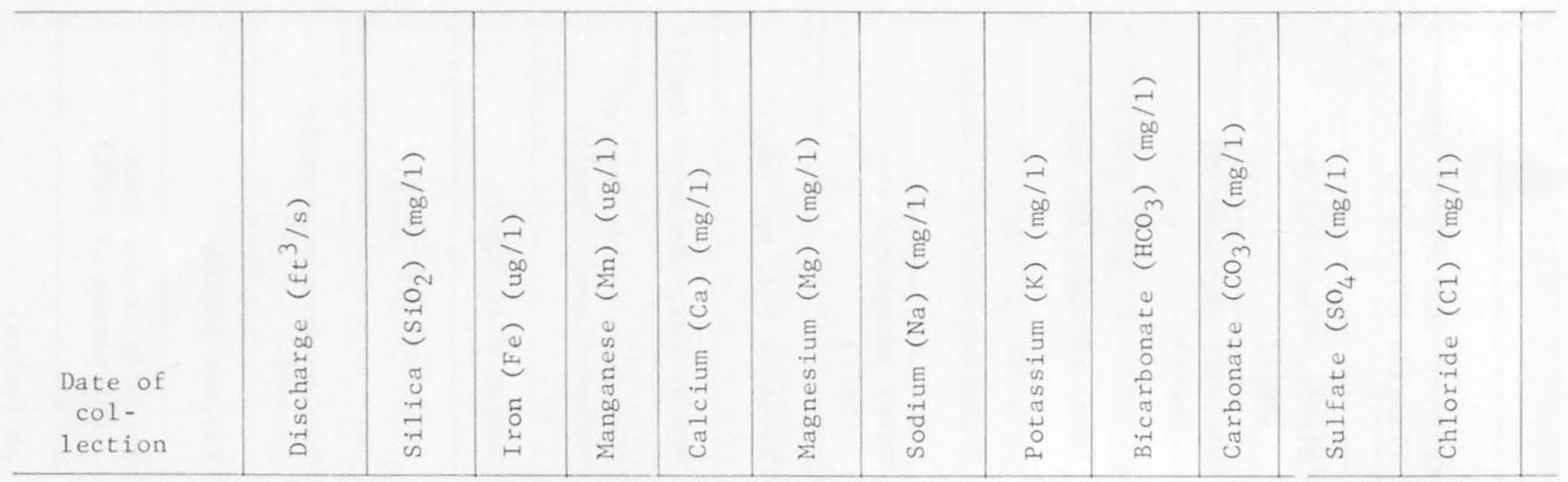

\begin{tabular}{|c|c|c|c|c|c|c|c|c|c|c|c|c|}
\hline $\begin{array}{l}\text { Mar. } 31,1972 \\
\text { June 22, } 1972 \\
\text { Feb. 8, } 1973 \\
\text { Apr. 17, } 1973 \\
\text { June 13, } 1973\end{array}$ & $\begin{array}{c}176 \\
103 \\
6.0 \\
10 \\
8.8\end{array}$ & $\begin{array}{l}19 \\
13 \\
22 \\
19 \\
28\end{array}$ & $\begin{array}{r}550 \\
110 \\
110 \\
60 \\
140\end{array}$ & $\begin{array}{r}-- \\
82 \\
20 \\
0 \\
20\end{array}$ & $\begin{array}{l}36 \\
48 \\
58 \\
51 \\
44\end{array}$ & $\begin{array}{l}16 \\
21 \\
39 \\
23 \\
19\end{array}$ & $\begin{array}{l}36 \\
41 \\
84 \\
49 \\
43\end{array}$ & $\begin{array}{l}9.1 \\
8.9 \\
18 \\
13 \\
9.9\end{array}$ & $\begin{array}{l}266 \\
354 \\
534 \\
366 \\
316\end{array}$ & $\begin{array}{l}0 \\
0 \\
0 \\
0 \\
0\end{array}$ & $\begin{array}{l}13 \\
7.6 \\
48 \\
15 \\
11\end{array}$ & $\begin{array}{r}7.7 \\
5.2 \\
18 \\
12 \\
5.8\end{array}$ \\
\hline & & & & & & & & & & & \multicolumn{2}{|c|}{ Malheur Lake } \\
\hline $\begin{array}{ll}\text { Mar. 28, } & 1972 \\
\text { June 21, } & 1972 \\
\text { Apr. 24, } & 1973\end{array}$ & -- & $\begin{array}{l}13 \\
14 \\
22\end{array}$ & $\begin{array}{l}80 \\
60 \\
40\end{array}$ & $\begin{array}{r}-- \\
30 \\
0\end{array}$ & $\begin{array}{l}43 \\
43 \\
41\end{array}$ & $\begin{array}{l}20 \\
31 \\
35\end{array}$ & $\begin{array}{r}52 \\
110 \\
140\end{array}$ & $\begin{array}{l}11 \\
25 \\
34\end{array}$ & $\begin{array}{l}338 \\
569 \\
554\end{array}$ & $\begin{array}{r}0 \\
0 \\
49\end{array}$ & $\begin{array}{l}17 \\
40 \\
41\end{array}$ & $\begin{array}{l}9.4 \\
19 \\
23\end{array}$ \\
\hline
\end{tabular}

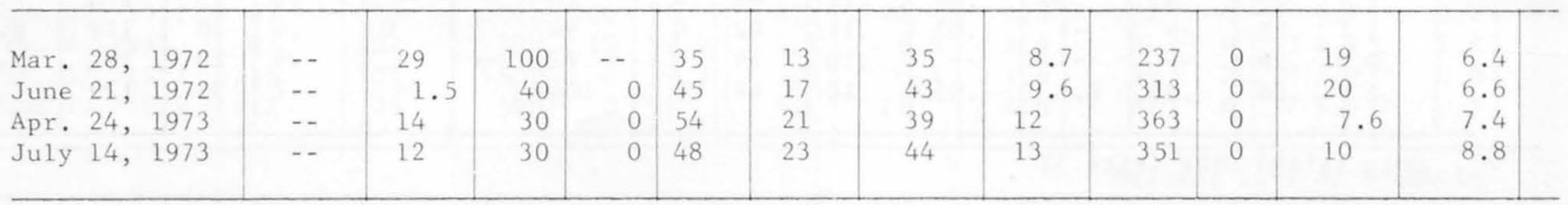

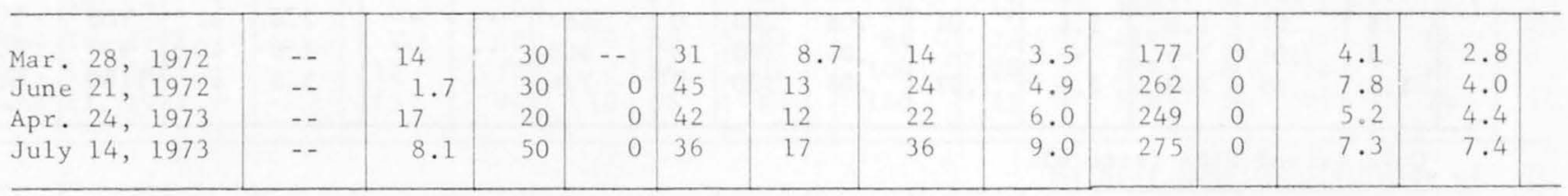

Malheur Lake

\begin{tabular}{|c|c|c|c|c|c|c|c|c|c|c|c|c|}
\hline Mar. 28, 1972 & -- & 21 & 60 & - & 41 & 18 & 51 & 11 & 308 & 0 & 21 & 9.9 \\
\hline June 21, 1972 & - & 18 & 30 & 0 & 49 & 24 & 56 & 14 & 383 & 0 & 22 & 9.7 \\
\hline Apr. 24, 1973 & - & 17 & 50 & 0 & 53 & 30 & 87 & 23 & 499 & 0 & 23 & 15 \\
\hline Ju1y 14, 1973 & -- & 21 & 230 & 0 & 53 & 35 & 98 & 24 & 547 & 0 & 26 & 19 \\
\hline
\end{tabular}

Malheur Lake

\begin{tabular}{l|r|r|r|r|r|r|r|r|r|r|r|r|r|r|}
\hline Mar. 28, 1972 & -- & 14 & 20 & - & 34 & 8.2 & 15 & 3.6 & 174 & 0 & 4.0 & 3.2 & 15 \\
Apr. 24, 1973 & -- & 13 & 9 & 0 & 38 & 9.9 & 18 & 4.1 & 210 & 0 & 4.9 & 3.8 & \\
\hline
\end{tabular}

Sodhouse Spring near

\begin{tabular}{l|l|l|l|l|l|l|l|l|l|l|l|l|l|l|}
\hline Oct. 16, 1973 & 12 & 40 & 50 & -- & 22 & 13 & 35 & 4.8 & 208 & 0 & 10 & 7.3 & \\
\hline
\end{tabular}




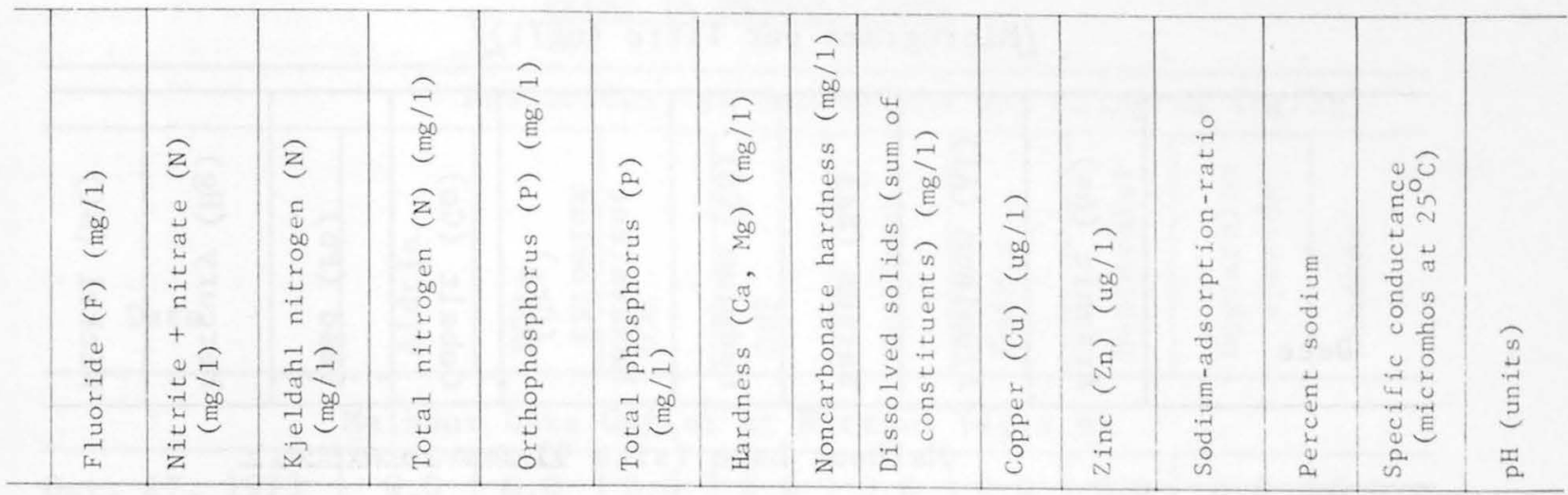

at Narrows (site 8 )

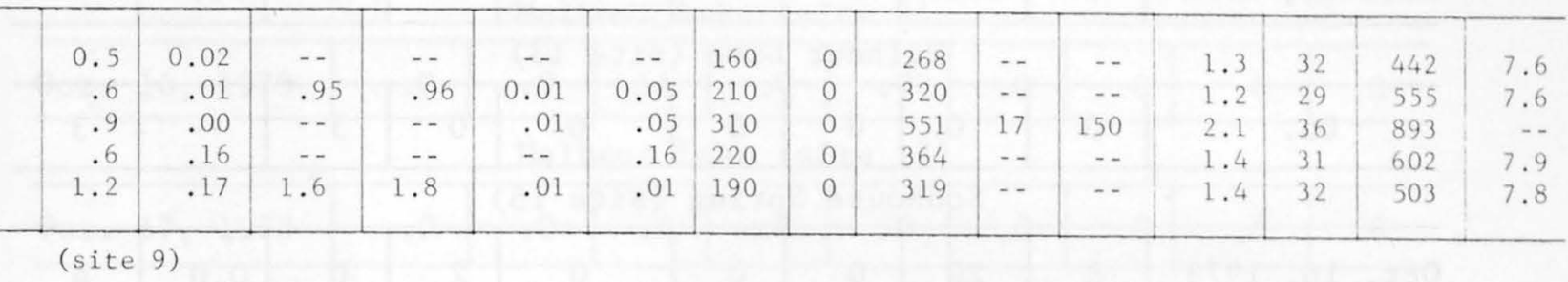

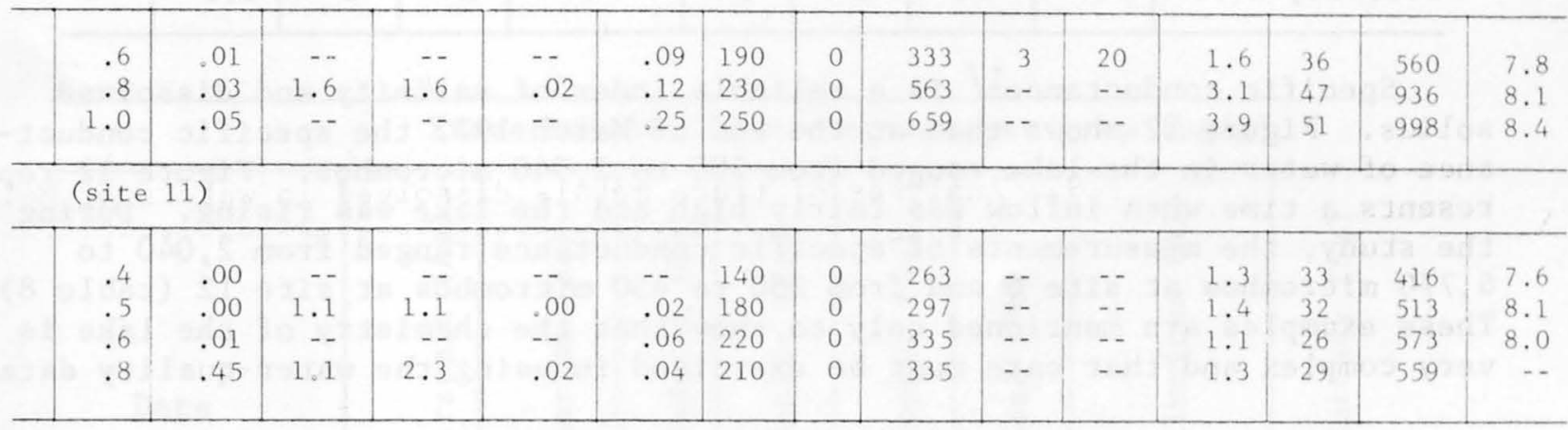

(site 12)

\begin{tabular}{|l|l|l|l|l|l|l|l|l|l|l|l|l|l|l|l|}
\hline .3 & .00 & .48 & .48 & -- & .05 & 110 & 0 & 166 & 7 & 20 & .6 & 21 & 280 & 7.6 \\
.3 & .03 & .86 & .89 & .00 & .04 & 170 & 0 & 230 & - & - & .8 & 23 & 394 & 8.1 \\
.4 & .00 & -- & -- & -- & .09 & 150 & 0 & 232 &.- & -- & .8 & 23 & 397 & 7.8 \\
1.5 & .24 & .95 & 1.3 & .01 & -- & 160 & 0 & 259 & - & -- & 1.2 & 31 & 450 & 8.1 \\
\hline
\end{tabular}

(site 13)

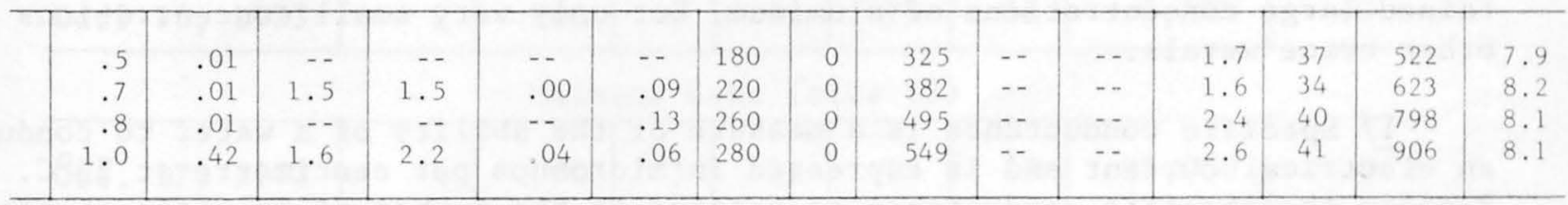

(site 14)

\begin{tabular}{|l|l|l|l|l|l|l|l|l|l|l|l|l|l|l|}
\hline .3 & .00 & -- & -- & - & -- & 120 & 0 & 168 & - &.- & .6 & 21 & 282 & 7.6 \\
.3 & .01 & -- & - & - & .07 & 140 & 0 & 196 &.- &.- & .7 & 22 & 335 & 7.7 \\
\hline
\end{tabular}

Voltage (site 15)

\begin{tabular}{l|l|l|l|l|l|l|l|l|l|l|l|l|l|l|l|l|l|l|l|l|l|l}
\hline .6 & .38 & $\ldots$ & $\ldots$ & $\ldots$ & .18 & 110 & 0 & 237 & 5 & 10 & 1.5 & 40 & 361 & 7.8 \\
\hline
\end{tabular}


Table 9.--Analyses of trace metals dissolved in waters of Ma1heur Lake

LMicrograms per litre (ug/1) $/$

\begin{tabular}{|c|c|c|c|c|c|c|c|c|c|}
\hline Date & 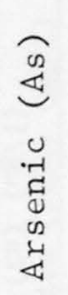 & 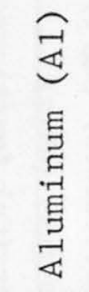 & 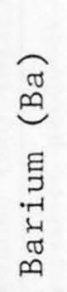 & 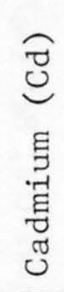 & 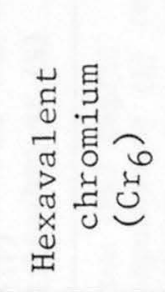 & $\begin{array}{l}0 \\
0 \\
+1 \\
-1 \\
0 \\
0 \\
0\end{array}$ & 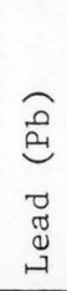 & 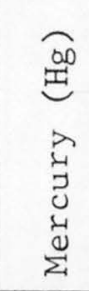 & 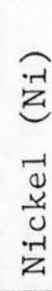 \\
\hline \multicolumn{10}{|c|}{ Malheur Lake (site 9) } \\
\hline Mar. 28, 1972 & 9 & 200 & 0 & 0 & 0 & 1 & 2 & 0.2 & 2 \\
\hline \multicolumn{10}{|c|}{ Malheur Lake (site 13) } \\
\hline Do. & 0 & 0 & 0 & 0 & 0 & 0 & 3 & -- & 3 \\
\hline \multicolumn{10}{|c|}{ Sodhouse Spring (site 15) } \\
\hline Oct. 16, 1973 & 8 & 20 & 0 & 0 & 0 & 2 & 0 & 0.0 & 4 \\
\hline
\end{tabular}

Specific conductancel/ is a reliable index of salinity and dissolved solids. Figure 12 shows that at the end of March 1972 the specific conductance of water in the lake ranged from 280 to 2,040 micromhos. Figure 12 represents a time when inflow was fairly high and the lake was rising. During the study, the measurements of specific conductance ranged from 2,040 to 6,770 micromhos at site 6 and from 280 to 450 micromhos at site 12 (table 8). These examples are mentioned only to show that the chemistry of the lake is very complex and that care must be exercised in using the water-quality data.

this study.

Detailed interpretation of the water-quality data is beyond the scope of

Bottom-sediment samples taken from sites 8, 9, and 12 (fig. 12) were analyzed for pesticides and trace metals (table 10). No pesticides were found in the bottom deposits from site 8 . Small quantities of DDE were found in samples from sites $9(0.4 \mathrm{ug} / \mathrm{kg})$ and $12(0.8 \mathrm{ug} / \mathrm{kg})$. A11 three samples contained large concentrations of aluminum, but only very smal1 concentrations of other trace metals。

1/ Specific conductance is a measure of the ability of a water to conduct an electrical current and is expressed in micromhos per centimetre at $25^{\circ} \mathrm{C}$. Because the specific conductance is related to the number of specific chemical types of ions in solution, it can be used for approximating the dissolvedsolids content in the water. Commonly, the amount of dissolved solids (in milligrams per litre) is about 65 percent of the specific conductance (in micromhos). This relation is not constant from stream to stream nor from well to well, and it may even vary in the same source with changes in the composition of the water. 
Table 10.--Chemical analyses of bottom-sediment samples at miscellaneous sites in Malheur Lake

\begin{tabular}{|c|c|c|c|c|c|c|c|c|c|}
\hline \multicolumn{10}{|c|}{ Pesticides, in micrograms per kilogram (ug/kg) } \\
\hline Date & 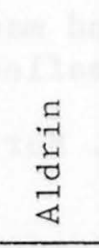 & 完 & 喠 & 客 & 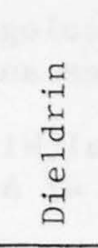 & 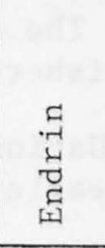 & 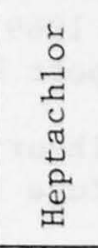 & 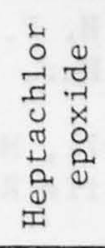 & 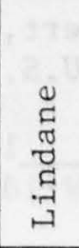 \\
\hline \multicolumn{10}{|c|}{ Malheur Lake Outlet at Narrows } \\
\hline Oct. 17,1973 & 0.0 & 0.0 & 0.0 & 0.0 & 0.0 & 0.0 & 0.0 & 0.0 & 0.0 \\
\hline \multicolumn{10}{|c|}{ Ma1heur Lake (site 9) } \\
\hline Oct.16, 1973 & .0 & .0 & .4 & .0 & .0 & .0 & .0 & .0 & .0 \\
\hline \multicolumn{10}{|c|}{ Malheur Lake (site 12) } \\
\hline Oct. 17,1973 & .0 & .0 & .8 & .0 & .0 & .0 & .0 & .0 & .0 \\
\hline
\end{tabular}

\begin{tabular}{|c|c|c|c|c|c|c|c|c|}
\hline \multicolumn{9}{|c|}{ Trace metals, in micrograms per gram (ug/g) } \\
\hline Date & 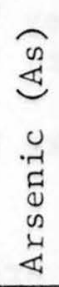 & 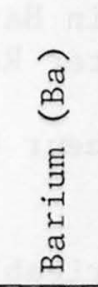 & 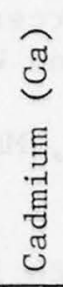 & $\begin{array}{l}0 \\
0 \\
0 \\
+1 \\
-10 \\
0 \\
0 \\
0\end{array}$ & 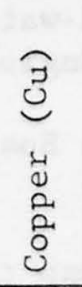 & 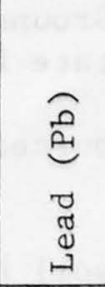 & 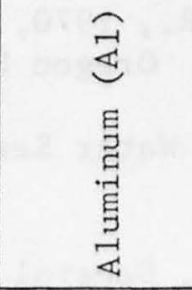 & 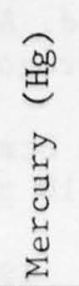 \\
\hline \multicolumn{9}{|c|}{ Ma1heur } \\
\hline Oct. 17,1973 & 3 & 50 & 1 & 10 & 10 & 10 & 10,000 & 0.0 \\
\hline \multicolumn{9}{|c|}{ Malheur Lake (site 9) } \\
\hline Oct. 16,1973 & 2 & 100 & 3 & 12 & 79 & 30 & 5,200 & .0 \\
\hline \multicolumn{9}{|c|}{ Malheur Lake (site 12) } \\
\hline Oct. 17,1973 & 4 & 80 & 3 & 21 & 17 & 17 & 29,000 & .0 \\
\hline
\end{tabular}




\section{SELECTED REFERENCES}

Cruff, R. W., and Thompson, T. H., 1967, A comparison of methods of estimating potential evapotranspiration from climatological data in arid and subhumid environments: U.S. Geol. Survey Water-Supply Paper 1839-M, 28 p.

Duebbert, H. F., 1969, The ecology of Malheur Lake and management implications: U.S. Bur. Sport Fisheries and Wildlife Refuge leaflet 412, 24 p.

1971, Malheur National Wildlife Refuge: U.S. Bur. Sport Fisheries and Wildlife Refuge leaflet 47 A-R.

Funk, W. H., 1972, Final report on the preliminary investigation of the water quality of Malheur Lake and major tributaries: Mimeo. rept. prepared for Corps of Engineers, Walla Walla Dist., $51 \mathrm{p}$.

Gay, L. W., and Holbo, H. R., 1971, Evaporation study - Ma1heur Lake, Silvies River drainage: School of Forestry, Oregon State Univ., Corvallis (mimeo, rept. prepared for Corps of Engineers, Walla Walla Dist.), 21 p.

Herzog, J. H., Rathja, R. C., and Murray, R. J., undated, ERTS-1 satellite data for monitoring seasonal variations in Malheur Lake: Dept. Elec. and Computer Eng., Oregon State Univ.,_Corvallis (mimeo. Pictorial Inf. Extraction and Enhancement Lab. IPIXEL/ Tech. Rept. 052074).

Kohler, M. A., Nordenson, T. J., and Baker, D. R., 1959, Evaporation maps for the United States: Weather Bureau Tech. Paper 37, 13 p.

Leonard, A. R。, 1970, Ground-water resources in Harney Valley, Harney County, Oregon: Oregon State Engineer Ground Water Rept。16, 85 p.

Oregon State Water Resources Board, 1967, Malheur Lake basin: Salem, Oreg., $110 \mathrm{p}$.

1969, Genera1 soil map report with irrigable areas, Malheur Lake drainage basin, Appendix I-12 of Oregon's 1ong-range requirements for water: Salem, Oreg., 79 p.

Piper, A. M., Robinson, T. W., and Park, C. F., Jr., 1939, Geology and groundwater resources of Harney Valley, Oregon: U.S. Geol. Survey Water-Supply Paper 841, 189 p.

U.S. Department of Agriculture, 1967, Water and related land resources, Malheur Lake drainage basin, Oregon: U.S. Dept. Agriculture Oregon River Basin Survey Staff, Salem, Oreg., 171 p. 